\title{
The Cancer Patient Drowns in the Waves of Homeostatic Disorder
}

\section{Z. Douvlis}

Landstr. 62, Wurthfleth, 27628 Hagen im Bremischen, Germany

Email: DrDouvlis@AOL.com

How to cite this paper: Douvlis, Z. (2018) The Cancer Patient Drowns in the Waves of Homeostatic Disorder. Journal of Cancer Therapy, 9, 650-688.

https://doi.org/10.4236/jct.2018.99056

Received: April 4, 2018

Accepted: September 3, 2018

Published: September 6, 2018

Copyright $\odot 2018$ by author and Scientific Research Publishing Inc. This work is licensed under the Creative Commons Attribution International License (CC BY 4.0).

http://creativecommons.org/licenses/by/4.0/

(c) (i) Open Access

\begin{abstract}
Neoplastic cells are formed as a result of reprogramming the gene expression. It is only when these cells are classified as non-local by the normal cells that confrontation occurs, and thus cancer begins as a disease. The tumorogenic degradation of the skeletal muscle plays a highly important role in the pathomechanism of the disease. It transforms a diminishing differentiation into an increasing homeostatic disorder, and is forced to provide energy to the malignant cells. This characterizes the completed form of the pathomechanism. Blocking the pathomechanism is the goal of a therapy that can be realized on two levels: At the level of reprogramming of the gene expression, which initiates the formation of neoplastic cells, a "reprogramming" of the reprogramming of gene expression could be achieved by altering the genomic flow of information. Increased anabolism (corresponding to the nutrient surplus) as well as increased catabolism (corresponding to nutrient) could lead to respective changes of the flows of genomic information. These opposing flows in a patient could be expected to result in interference or a shearing effect. Patients with acromegaly exhibit a 9.25\% increased neoplasia prevalence, whilst patients with hyperthyroidism have $8.41 \%$ increased neoplasia prevalence. Patients with acromegaly and hyperthyroidism have a lower prevalence of neoplasia of $3.30 \%$, i.e. the chance of these patients not contracting cancer is three times greater than patients with either only acromegaly or only hyperthyroidism. At the level of tumorogenic degradation of skeletal muscle, inhibition of muscle degradation by means of hypertriglyceridemia results in a significant prolongation of the life of carcinoma patients. This is based on the fact that inhibition of muscle degradation occurs after infusion of triglyceride emulsion. In the case of $S$. sanguinis bacteremia, there may be an interaction between enzymes from $S$. sanguinis, from the digestive tract and from the tumor. The source of infection determines the inactivation of the tumor enzyme and thus suppresses tumor development.
\end{abstract}




\section{Keywords}

Interference of Genomic Information Flows, Optimization of Neoplastic Dynamics, Asymmetric Catabolism, Lactate Gradient, Variability of Malignancy, Cachexia with Good Nourishment

\section{Introduction}

The pathomechanism of the cancer disease is based on progressive morphofunctional destruction.

If the cells of the unregulated autonomous growth have a great resemblance to the tissue from which they were formed, they are not classified by the local cells as a non-local. A separate proliferation and the formation of a benign tumor, occur.

The characteristic feature of benign tumors is, amongst other things, slow growth. In contrast to malignomas, benign tumors display a microscopically sharp border with normal tissue and an absence of lymphoplasmacellular infiltrates, which are almost always found in malignant neoplasia. However, nothing has been written about the degradation of skeletal muscle and weight loss [1] [2].

If the cells of the uncontrolled autonomous growth have no resemblance to the tissue from which they are originate, they are then classified by the local cells as non-local. This leads to confrontation and revelation of the malignant properties of the tumor cells [1]. It can be assumed that the resulting cell debris forms a feeder-layer and promotes proliferation.

"The somatic body cells are usually localized and can only survive and reproduce in the organ or milieu in which they physiologically belong. If, for example, because of traumatic reasons, they are transferred to other regions than the ones they originate from, then they perish [3]". "This represents a local cell barrier against non-local cells, probably based on the individuality of the different organs."

"Here and in the entire body periphery, they (amino acids) are once again converted into protein in the cells and the tissues, and not only species-specific, but also individual-specific and organ-specific" [4].

"All neoplastic tissues do not contain as many free amino acids as their mother tissue, and exhibit, no matter which tissue they originate from, in many respects a very similar composition to the free amino acids, while normal tissue has its own characteristic distribution" [5].

It can be concluded from this that the free amino acids distribution pattern, characteristic for each organ, causes a functional interaction among the cells of an organ leading to the formation of the organ specificity. This forms a barrier between the local cells and the non-local cells including the tumor cells. In this respect, the aim of the tumor cells is the destruction of the distribution pattern of the free amino acids characteristic for each organ. 
If the tumor cells break through barrier to the local cells during this confrontation, this leads to a primary tumor formation. The invasion of the tumor cells originates from the invasive compartment of the primary tumor [6], and continues as a result of the expansion pressure caused by its own growing cell mass. That means the tumor cells use the proliferation expansion pressure as an instrument to destructively displace the normal cells (destructive invasion).

"However, in contrast to the invasion of the interstitial matrix of the host tissue, enzymatic processes apparently do not play any role here, but rather the shrinkage of the host tissue is, as our study has shown, the result of progressive pressure atrophy" [7].

The tumor cell proliferation expansion pressure instrument is supported by the pointed shape of the cells on the invasive front. There, the tumor cells exhibit anything from incomplete to missing formations of junctional complexes with, characteristically, the sharp ends pointing in the invasive direction [7]. It can be assumed that the tumor cells on the invasive front are pushed like wedges between the normal cells by the proliferation expansion pressure. The adjacent tissue is "ploughed up", a phenomenon absent in the case of benign tumor expansion, probably due to ATP depletion in the microenvironment of the tumor.

"The metabolic microenvironment of solid tumors is characterized by an oxygen deficiency and increased anaerobic glycolysis leading to extracellular acidosis and ATP depletion" [8].

ATP depletion causes disruption in the case of desmosomes and gap junctional complexes [9]. The reduction of gap junctional intercellular communication leads to an increase in the spreading of cells [10].

This is also likely to be the reason why tumors have been described as "wounds that do not heal" [11]. The composition of the tumor stroma is comparable with granulation tissue formed during the course of the wound healing. However, a final product comparable to the physiological wound healing is not achieved [12]. This is probably due to ATP depletion in the tumor microenvironment since, following the first phase of physiological wound healing, a switch to the aerobic metabolism [13] occurs, which is not to be expected in the microenvironment of the tumor.

Apart from that, the low ATP yield in the case of aerobic glycolysis [14] can also be interpreted as a successful attempt by the tumor cells to "shut down" ATP production in order to avoid the anti-tumor effect of ATP [15].

The time interval between tumor cell dissociation from the primary tumor and the onset of metastasis can be characterized as a reduction phase and, from a clinical viewpoint, as an eclipse. In this interval, the metastasizing cascade decreases, accompanied by an increasing loss of tumor cells, due to mechanical stress. [6] [16]. On the boundary surfaces of moving fluids, e.g. on the vascular wall, thrust or shear forces occur due to the friction of the moving fluids [17]. Accordingly, it can be assumed that the tumor cells which pass through the wall of a blood vessel are subjected to such shear forces of the flowing blood. As the 
tumor cells exhibit impaired structures [18], it is likely that this mechanical stress causes massive destruction of the tumor cells.

The second proliferation phase begins with the formation of metastases. While cell proliferation, which leads to the formation of the primary tumor, occurs in the mother tissue, cell proliferation in the case of the formation of metastases occurs in the non-local tissue. The formation of metastases leads to a reduction in the degree of differentiation.

"The degree of differentiation of the neoplasia is reduced in the metastases compared to the primary tumor" [1].

"However, the malignant properties resulting from the transformation are not recognizable in the tissue culture, but rather only become apparent after re-implantation of cells into the laboratory animal organism" [1].

"The in vivo absorption capacity of the tumor is limited by the relatively small, and mainly peripheral, supply of the tumor" [5]. Due to the supply bottleneck in which they find themselves in after the implantation, it is to be assumed that the implanted tumor cells are forced into a confrontation course in order to exploit a feeder layer. As a result, they are forced to develop a higher malignancy or higher destruction dynamics, which should also apply for the cells that form the metastases. This can be compared to an electric drill: if the drill hits a higher resistance, the drill takes more power out of the net. The higher malignancy is to be seen as a response to the higher resistance, which provokes an increase in the proliferation and leads to a rise in the expansion pressure. The proliferating tumor cells require a higher, glycolitic supply of energy. There is an increase in lactate production, which correlates with a reduction in the differentiation (inverse correlation) [19] [20]. The positive correlation between the degree of differentiation and malignancy [21] is influenced by the decreasing degree of differentiation, resulting in a progressive malignancy development.

"Cancer metastases, for example, in the liver or lungs, are almost always present in countable numbers, comparable with the smallest-scale 'millet' dispersion of miliary tuberculosis" [22]. This ratio results in a disproportional impairment of physiological functions relative to the number of metastases. This leads to the likelihood that the cells of the metastases develop additional abilities besides local destructions. The fact that the outcome of the disease is decided by the metastases in $90 \%$ of the patients [22] can be attributed to the "additional abilities" of the metastasized cells, which would be explained by the reduced degree of differentiation compared to that of the primary tumor [1].

All neoplastic tissues contain fewer free amino acids than the mother tissue, and in many respects show a very similar composition to the free amino acids, no matter from which tissue they have originated, whereas normal tissues exhibit their own respective characteristic distribution [5]. It is due to this that the initiation of the pathomechanism can be recognized. The free amino acids of the neoplastic tissues have the ability and possibility (locally) to destroy the organ-specific amino acid patterns, thus breaking down the barrier between the local cells and the non-local cells. 
The release of amino acids in a generalized form takes place as a result of the forced catabolism in the skeletal muscle when a tumor is present, whereby the periphery of undernourished carcinoma patients releases more amino acids than the periphery of undernourished control subjects without carcinoma [23]. This, in conjunction with the absence of skeletal muscle degradation when a benign tumor is present [2], suggests that the released amino acids form the basis of the pathomechanism that includes the tumor-bearing organism in its entirety.

Not only the concentrations, but also the relative composition of the amino acids can have a pathological effect on the normal cells if they are not subjected to physiological controls such as those of the intestines and liver [24]. The fact that there is an imbalance in the concentrations of the amino acids in the plasma of tumor patients [25], speaks in favour of a circumvention of the control mechanisms. This can be regarded as a stochastic distribution of the amino acids, and would correspond to a parenteral supply of amino acid without physiological adjustment. The consequence of such a situation would be a homeostatic disorder of the amino acids [24].

"Indeed, there are few differences in the enzyme profiles of well-differentiated tumor cells from those of their normal counterparts" [26], thus indicating a change in the enzyme pattern with decreasing differentiation. From this, it can be concluded that the degradation of the skeletal muscles, when a malignancy is present, is due to a change in the aggressiveness of the enzyme, which, in turn, correlates with a decreasing degree of differentiation. The fact that in the case of $90 \%$ of patients the outcome of the disease is determined by the metastases [22], and that "The degree of differentiation of neoplasia is reduced in the metastases compared to the primary tumor" [1], suggests that the enzyme pattern changes to more immature and more aggressive variants.

The pathomechanism of the cancer disease can be deduced from this. This involves the development of a diminishing differentiation which acts as promoter in the case of degradation of the skeletal muscle with the release of amino acids. This, in turn, forces the homoeostatic disorder, thus leading to devitalization of the tumor-bearing organism.

\section{Enzymatic Degradation of Skeletal Muscle}

It is to be assumed that the degradation of skeletal muscle would have to take place by the action of an enzyme produced in, and secreted from, the tumor cells. This enzyme would correspond to the degree of "de-differentiation" (in the sense of a reduction of the degree of differentiation of the malignant cells) of the tumor cells and may be called RMDP (reverse muscle degradation protease). This raises the question whether this enzyme was present in the tumor cells from the outset, or is produced and secreted only upon contact with skeletal muscle.

The metastasization process is accompanied by a high cell loss [6]. If the enzyme RMDP were present in the malignant tumor cells from the outset, there would be a massive leakage of the enzyme RMDP from the tumor cells, which 
are destroyed on a massive scale during metastasis. On the basis of an organotropy, this enzyme would reach the skeletal muscles relatively early and on a massive scale. The intensity of the symptoms triggered by this would be comparable with the symptoms of a Herxheimer reaction [27].

It would be more probable that the malignant cells synthesize and secrete the enzyme RMDP only after contact with the skeletal muscle. This possibility contradicts, however, the observation that the skeletal muscle is hardly affected by metastases [2].

However, the fact that skeletal muscle is hardly affected by metastases does not exclude the fact that malignant cells nevertheless metastasize into the skeletal muscle, secrete their enzymes there and perish after a relatively short period of time. This supports the existence of, generally controversial [21], occult metastases.

According to the reasoning, the enzyme RMDP causes the release of amino acids from the skeletal muscle in order to distort, in a generalized form, the organ-specific characteristic pattern of the free amino acids. The local and generalized forms provide the basis for the initiation of morphofunctional destructions. The enzyme RMDP, a tumor protein, cannot be degraded as a defective protein by the host organism, since "even in the case of starvation, if body weight and liver proteins are already considerably reduced, the tumor proteins cannot be utilized by the host organism" [5]. From this point of view it is to be assumed that the enzyme RMDP as a retrogressed enzyme on the enzyme evolution scale which would correspond to the degree of "de-differentiation" of the tumor cells. This leads to the conclusion that proteases from non-highly developed organisms would have the capacity to deactivate the enzyme RMDP.

Streptococcal bacteriomas, including $S$. sanguinis, occur with high frequency in carcinoma patients [28].

Streptococcus sanguinis (formerly $S$. sanguis) is a member of the viridans group of streptococci. It is the first bacterium to colonize tooth surfaces, where it functions as a "pioneer" by forming dental plaque [29].

In general, the source of infection is either oral or in the gastrointestinal tract [28]. The colonization of the endocardium with $S$. sanguinis is also a source of infection.

Aryl amino peptidase, a streptococcus sanguinis enzyme, has the property of splitting polipeptides and oligopeptides [30], it would thus also be able to inactivate the enzyme RMDP from the tumor cells. However, the inactivating effect of aryl amino peptidase appears to depend on the source of the infection.

Of 78 patients with streptococcal/enterococcal bacteremia and cancer, 22 had bacteremia resulting from streptococcus sanguinis, of which 11 patients had solid tumors and the remaining 11 had hematologic neoplasms. No mention was made of an endocarditis in this $S$. sanguinis group. An entocarditis occurred in the streptococcus mitis group. Myocardial involvement was reported in the case of one patient of the enterococcus faecalis group and in an additional patient in group $\mathrm{G}$ of the beta hemolytic streptococci group [28]. In contrast, 52 patients 
had streptococcal sanguine endocarditis and bacteremia. In this context please refer to 46 individual publications [31]-[76]. In addition, one patient had neoplasia in the lungs [31] and two further patients also had a myxoma [59] and [60].

The differing prevalence of neoplasia in the case of $S$. sanguinis bacteremia depends on the source of the infection because this determines which enzymes are involved. They are: Arylaminopeptidase from the $S$. sanguinis, the enzyme RMDP from the tumor cells, which is responsible for the degradation of the skeletal muscle, and the digestive enzymes of the gastrointestinal tract.

In the case of $S$. sanguinis endocarditis with bacteremia, the enzyme arylaminopeptidase enters directly into the blood. It consequently bypasses the enzymes of the gastrointestinal tract, remains in an active form and inactivates the enzyme RMDP from the tumor cells. In the case of 52 patients with $S$. sanguinis bacteremia and endocarditis, only one neoplasia (lung) was reported, while on the other hand in the case of 22 neoplasia patients with $S$. sanguinis bacteremia no endocarditis was reported. This can be explained by the fact that, in general, the source of infection for $S$. sanguinis is oral or in the gastrointestinal tract (28), that the arylaminopeptidase remains active in the case of $S$. sanguinis endocarditis and consequently tumor development is suppressed.

In the presence of a tumor (malignancy), a forced degradation of the skeletal muscle occurs [23]. This means that in the case of the suppression of the development of a tumor there can be no skeletal muscle degradation. It can thus be concluded that arylaminopeptidase inactivates the RMDP enzyme.

\section{Intra/Extracellular Lactate Gradient}

With regard to the occult metastases, it can be assumed that the malignant cells metastasize into the skeletal muscle but cannot form metastases there because they perish after a relatively short time. The malignant cells would, therefore, secrete the enzyme RMDP after contact with the skeletal muscle, in order to initiate the release of the amino acids during the degradation of the skeletal muscle. Skeletal muscle lactate production, which varies considerably, could lead to the destruction of the tumor cells in the skeletal muscle. At rest, the lactate concentration in the arterial blood is the range of $0.5 \mathrm{mmol} / \mathrm{l}$ to $16 \mathrm{mmol} / \mathrm{l}$. During exercise, in the skeletal muscle maximum values of $26 \mathrm{mmol} / \mathrm{l}$ have been measured in the working skeletal muscle [77]. It can be assumed that the lactate concentration in the skeletal muscle can reach values which, through blocking the lactate export from the tumor cells, lead to the destruction of their functions. This is supported by results from experimental work.

"We conclude that high lactic acid concentrations in the tumor environment block lactic acid export in the T-cells, thereby disturbing their metabolism and function" [78]. If the export of lactic acid from the T-cells is carried out along a gradient, then this is probably true for tumor cells. The malignant tumor cells produce lactic acid [79], which means that the export of the lactic acid from the tumor cells should only proceed along an intracellular/extracellular gradient. 
An inhibition, or blocking, of lactate export from tumor cells is probably the cause for the different frequencies of liver metastasis formation.

In cirrhosis of the liver the utilization of lactate, predominantly derived from muscles, is restricted by the liver [80]. The increase in lactate concentration to be expected by this can, depending on the level, lead to the blocking of lactate export from the tumor cells, and thus to a destruction of the latter. The metastatic frequency of $0.12 \%$ in cirrhotic livers, compared with a metastatic frequency of $28.6 \%$ in the normal livers, clearly supports this [81].

It should be noted that under the influence of lactate concentration the finding "... was however that the presence of cancer (excluding liver cancer) and liver cirrhosis was only present in $2.1 \%$ of the autopsies, whereas the overall cancer frequency was 19.4\%" [81]. This discrepancy is probably due to a sustained lactate concentration, since in the case of patients with liver cirrhosis, the lactate half-life is significantly prolonged [82].

In the case of hepatocellular carcinoma (HCC), on the basis of liver cirrhosis, the effect of lactate accumulation on the lactate export from the tumor cells does not appear to be obstructive.

This is due to the lack of inhibition of intracellular lactate export from the tumor cells, because in this case the lactate is released directly into the blood. In the case of HCC: "The tumor cells have almost always infiltrated the blood vessels ... The invasion of the tumor into the liver veins is an important differential diagnosis criterion for distinguishing a hepatocellular carcinoma from metastases" [83].

If the lactate export from the tumor cells occurs without a special inhibition of the intra/extracellular lactate gradients, this appears to have a suction effect on the glucose flow which may lead to the high glycolysis in HCC [84].

Similar behavior can be observed with other tumor entities. Cervical, head and neck cancer to name but a few have a relatively high vascular density and are characterized by a relatively high lactate concentration and poor prognosis [85]. It can thus be concluded from this that a corresponding lactate gradient is formed, which determines the magnitude of the lactate perfusion through the vascular wall. This is because increasing the product removal rate increases the supply rate which results in this product. [86]. The "Accumulation of lactate within tumors has been correlated with poor clinical outcomes" [87], refers to the combination of lactate accumulation and a deterioration of the clinical course of the disease, and this is a consequence of the diminishing degree of differentiation. There is a positive correlation between growth rate, glycolysis magnitude and malignancy [88], as well as between degree of malignancy and differentiation [21].

An increase in the rate of removal of the product (lactate) provokes an increase in the rate of the supply of glycolytic energy which leads to further lactate production. On the basis of the inverse correlation between lactate production and differentiation [19], this results in a reduction of the differentiation and on the basis of the negative correlation between differentiation and proliferation 
[89] an increase in the proliferation.

In one case of lactate acidosis in a female patient with high-grade non-Hodgkin lymphoma, attempts have been made to treat the lactate acidosis with a daily dose of 100 mmol sodium bicarbonate, but there was a further deterioration [90]. In this case, the rate of product removal (lactate) was increased by treatment with sodium bicarbonate, which led to a further increase in lactate production [86]. In this regard, it has been pointed out in a publication that raising the $\mathrm{pH}$ value by administering sodium bicarbonate should be considered as contraindicated [91].

The frequency of vaginal metastases also displays a dependence on the lactic acid content of the vaginal secretion. This contains lactic acid resulting from enzymatic cleavage of glycogen by the Döderlein bacillus under the influence of estrogens [92]. Most women go through the menopause between the ages of 45 and 55, with the downward trend of the estrogen curve beginning at the age of 45 [93].

At the onset of the menopause, lactobacilli are detached from various aerobic and obligate or facultative anaerobic bacteria [92], resulting in a decline of lactic acid concentration in the vaginal secretion. From this point onwards, vaginal metastases frequency displays a steep increase (Figure 1).

42 publications report 105 cases of vaginal metastases, of which: 52 - 3 (3 without age details) $=49$, according to (V.C. Wright) [94], additional cases: 48 43 (43 are included in the 49) $=5$ according to (E. Moneta) [95] as well as 51 other individual cases [96]-[137].

Another example worth mentioning in this context is the heart, which is rarely affected by metastases [2]. In this case as well, the lactated environment plays a role, because in the heart muscle there is a continuous lactate degradation and conversion [138].

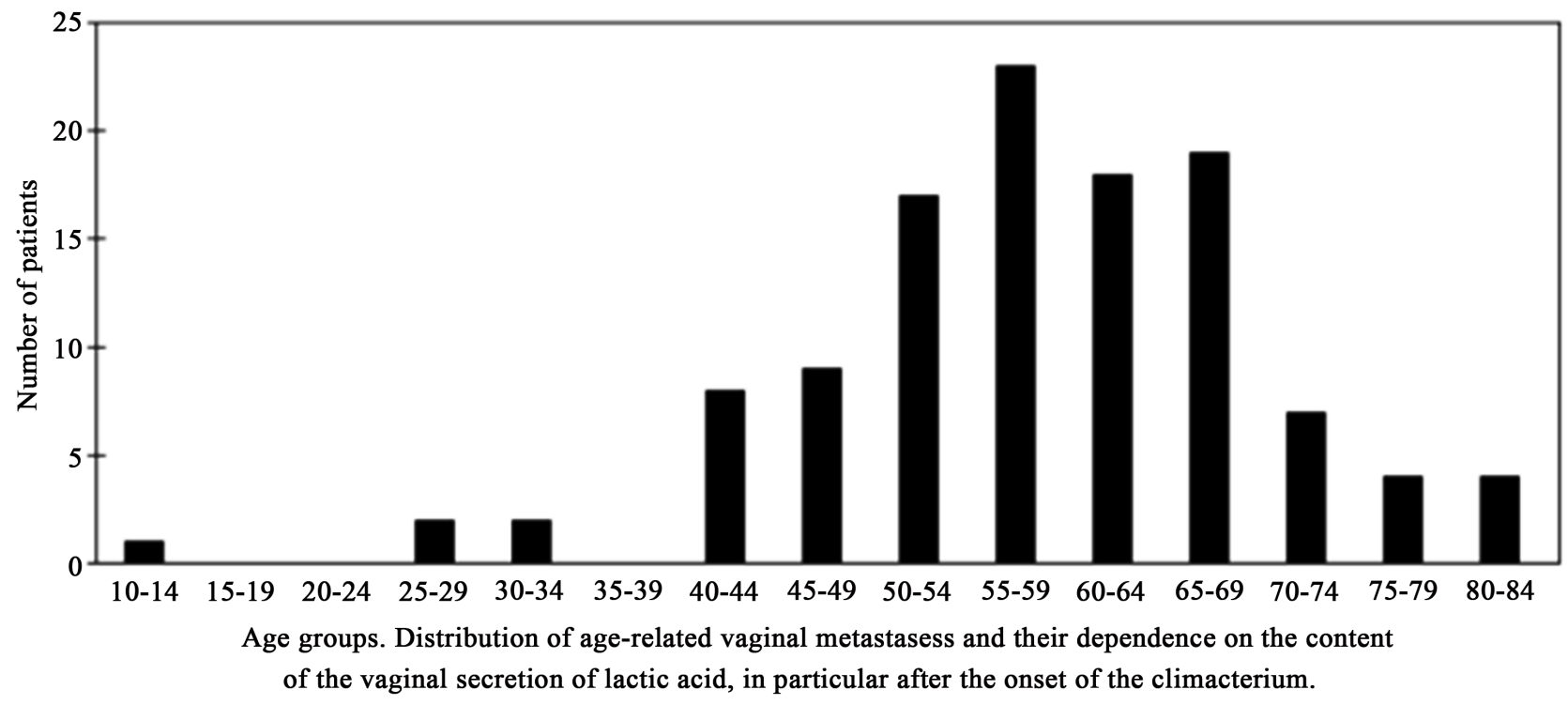

Figure 1. Vaginal metastases. 
In this context, infection of the spleen by metastases is subject to controversial discussion [2] [139].

\section{Contrasting Interactions}

In the case of therapy methods, e.g. chemotherapy or radiotherapy, there is an inhibition of proliferation and, depending on the dose, cytolysis. In general, proliferation inhibition is an inhibition against proliferation dynamics. From this point of view, inhibition together with simultaneous acceleration of proliferation (contrasting interaction) could apply more stress to the tumor cells. (Analogy: acceleration with handbrake applied). It could be expected that a higher stress would lead to a separation of the structures or functions (e.g. shearing effect), which would lead to an increase in apoptosis or necrosis, especially as the tumor cells exhibit impaired structures [18]. This is to be compared with the high cell losses in the case of the metastasization process due to mechanical action [6]. The development of resistance against the contrasting actions would occur as an increase in differentiation.

- A more pronounced anticancer effect was observed in the case of an intermittent calorie restriction than for a continuous calorie restriction [140].

"Previously we reported that intermittent calorie restriction (ICR) provided greater prevention of mammary tumors (MTs) than chronic calorie restriction (CCR)".

- "In the case of temperature-sensitive mutants, activation of the oncogene is temperature-dependent. Heating of the cell up to the permissive temperature leads to the development of the neoplastic phenotype within a very short period of time. After the lowering the temperature, the cell returns completely to the normal state" [141].

In these two examples, the contrasting effects occur in one after the other, the aim should be "simultaneous occurrence".

- It was demonstrated experimentally that tumor cell destruction rate after intraarterial injections in the muscle region was higher than after intraportal injections in the liver region [142]. The tumor cells are located intravascularly in a flowing state. In the muscle region, the intraarterial tumor cells are exposed to stronger friction forces as a result of muscle activity than the intravenous tumor cells in the liver veins. From this it can be concluded that there is a contrasting situation between the intravascular flow and the friction forces resulting from muscle activity which may lead to the formation of shear effects. This is supported by the higher rate of destruction of intravascular tumor cells in the muscle region.

- "If, however, C-myc overexpression is combined with cell cycle-occlusive agents, then, as demonstrated in two studies, this represents a potent apoptosis activator" [143].

- "We demonstrate that (a) short-term overexpression of native Myc protein in tet-mye cells causes a rapid induction of apoptosis in cells deprived of serum growth factors" [144]. 
In these cases the induction of apoptosis can be seen as the result of contrasting actions.

Numerous publications point to an anticancer effect in the case of a diet [145]. This could be due to the development of contrary interactions. The synthesis and inhibition of the degradation of proteins on the one hand and nutrient restriction on the other can result in a contrasting situation.

- "The metabolic response to dietary restriction involves a series of hormonal and metabolic adaptations leading to protein conservation, an increase in the serum level pf growth hormone $(\mathrm{GH})$, ...the effects of $\mathrm{GH}$ on protein metabolism seem to include both stimulation of protein synthesis and inhibition of breakdown" [146].

Inhibition of tumor growth under the influence of $\mathrm{GH}$ and malnutrition, i.e. (two contrasting objectives), was experimentally demonstrated by Sylvester P.W. [147].

- In 104 Sprangue-Dawley rats, mammalian tumors were induced by means of DMBA (7,12-dimethyl-benz (a) anthracene) and, for treatment purposes, divided into six groups A - F for an observation period of 26 weeks: Group A: 18 rats at fully fed, Group B: 18 rats underfed, Group C: 17 rats underfed + HAL (haloperidol), Group D: 17 underfed + GH (growth hormone), Group $\mathrm{E}: 17$ rats underfed + EB (estradiol benzolate) and Group F: 17 rats underfed $+\mathrm{HAL}+\mathrm{GH}+\mathrm{Eb}$. The number of tumors per rat at the end of the 26 th week are classified in groups: (Effects of different treatment of mammary tumors at the end of 26 weeks: Group A: 1.94, Group B: 0.64, Group C: 0.84, Group D: 0.46, Group E: 1.71, Group F: 2.35 .

The underfed tumor-bearing laboratory animals of Group D treated with GH showed 1) a more pronounced inhibition in the growth of the individual tumors and after the 21st week 2) the lowest number of developed tumors and 3) lowest increase in the growth curve.

From this it can be concluded that cell proliferation acceleration caused by the $\mathrm{hGH}$ and the negative effect of underfeeding on cell growth leads to the development of contrasting interactions. The result indicates not only tumor growth inhibition, but also an inhibition of tumor formation.

- Anabolism and catabolism occur simultaneously in a cell and in opposite directions [148]. They represent, in principle, a contrasting situation. In this case there is equilibrium between anabolism and catabolism under physiological conditions. It is to be assumed that increased anabolism and increased catabolism would induce corresponding changes in the genomic information flows.

In the case of nutrient excess or nutrient deficiency, there is a change in the genomic information flow which exerts an influence on the gene expression.

"Translational regulation is thus critical for gene expression, in particular, under nutrient excess or deficiency" [149].

If a nutrient excess, or a nutrient deficiency, leads to a change in the genomic 
information flow, a change in the genomic information flows would also be expected with increased anabolism and increased catabolism.

Therefore, patients with increased anabolism, as is the case of an acromegaly, as well as patients with catabolism, as is the case with hyperthyroidism, would have to exhibit changes in the genomic information flow.

A patient with (acromegaly + hyperthyroidism) is subject to the influence of two different, hormonal hyperfunctions. There is an increased anabolism as well as an increased catabolism. Both processes act in opposing directions and would correspondingly cause contrasting changes in the flows of genomic information, and consequently a contrary action is to be expected which may occur in the form of interference or a shearing effect. This would lead to a decrease in the prevalence of neoplasia in the case of a double disease.

hGH has an anabolic effect, oversecretion of hGH leads to acromegaly [150]. Hyperthyroidism leads to catabolism [151]. Patients with hyperthyroidism correlate with catabolism and with a greater accumulation of malignomas, because "hyperthyroidism promotes tumor growth in animals" [152]. Patients with an acromegaly exhibit increased anabolism and a higher risk of malignomas [153].

Thus with reference to greater accumulation of malignomas, it can be concluded that in the case of both acromegaly and hyperthyroidism, there is an underlying optimization of the neoplastic dynamics, which is expressed by the respective incidence. In this case (acromegaly and hyperthyroidism), a higher prevalence of neoplasia/malignomas would be expected than in the case of individual diseases.

Out of 4702 patients (acromegaly group) considered from several publications [153]-[161], 435 also had a neoplasm, which corresponds to a prevalence of 9.25\% (95\% confidence interval 8.44\% - 10.12\%). Out of 1938 patients (hyperthyroidism group) from a few publications [162] [163] [164], 163 also had a neoplasm. The prevalence is therefore $8.41 \%$ (95\% confidence interval $7.21 \%$ $9.74 \%$ ). Out of 91 patients (acromegaly + hyperthyroidism group) identified from 34 publications (165 - 199), only 3 patients also had neoplasia. The prevalence is therefore $3.30 \%$ (95\% confidence interval $0.69 \%-9.33 \%$ ).

The chance of not developing an additional neoplasm is thus almost 3 times higher if a patient has both underlying diseases (acromegaly + hyperthyroidism) than if a patient only has acromegaly (odds ratio, $\mathrm{OR}=2.991,95 \% \mathrm{CI}=[0.996$, 8.983]) and also almost 3 times as high as when a patient only has hyperthyroidism (odds ratio, $\mathrm{OR}=2.694,95 \% \mathrm{CI}=[0.882,8.229]$ ). The localization and number of neoplasms per group are listed in Tables 1-3.

It is well known that both acromegaly and hyperthyroidism are associated with an increased incidence of neoplasia. From this, it can be deduced that a neoplastic dynamic underlies both diseases. This suggests that an even higher prevalence of neoplasms would occur in patients with (acromegaly + hyperthyroidism). The prevalence would thus be higher than that of acromegaly alone 


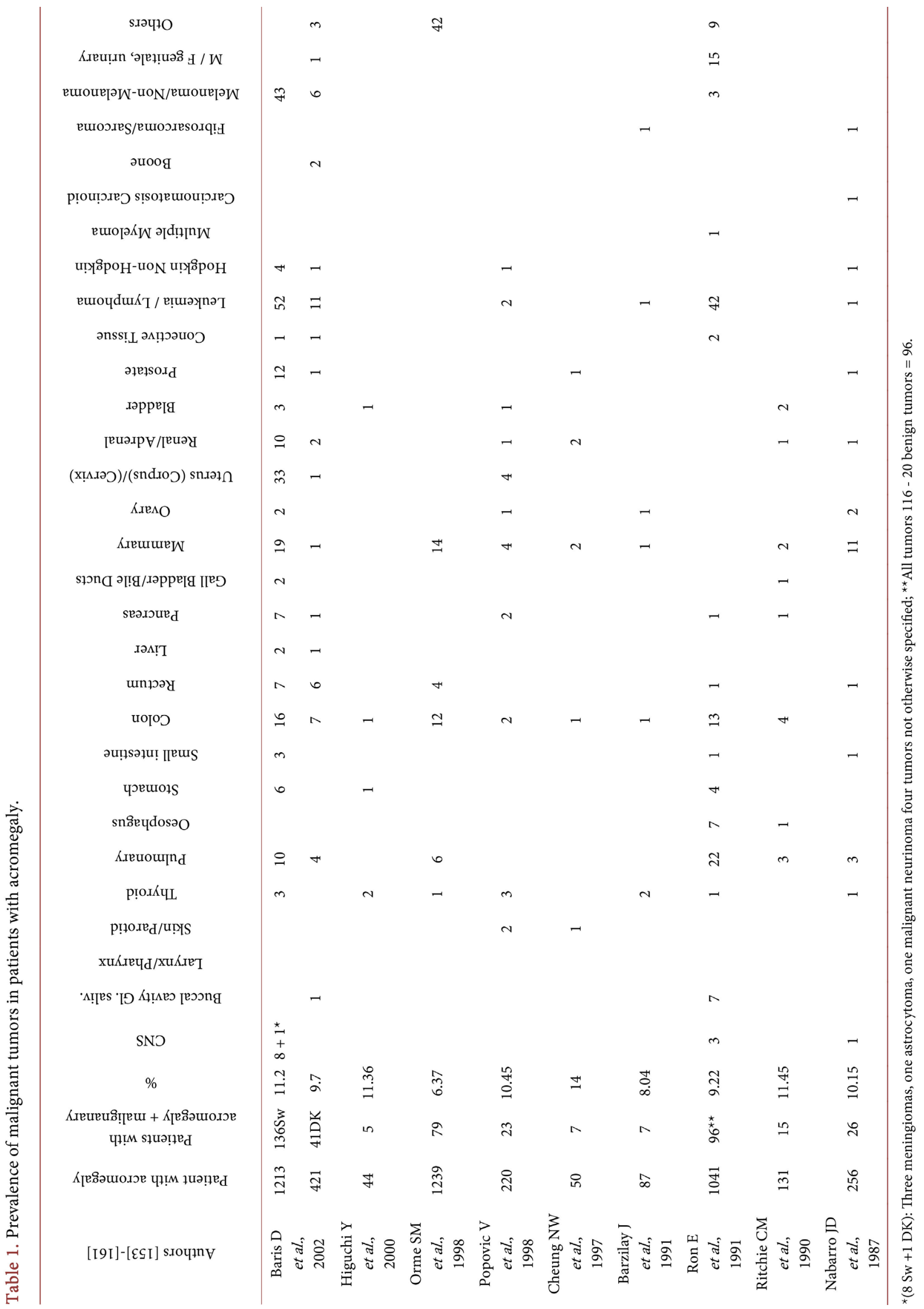


Table 2. Prevalence of malignant tumors in patients with hyperthyroidism.

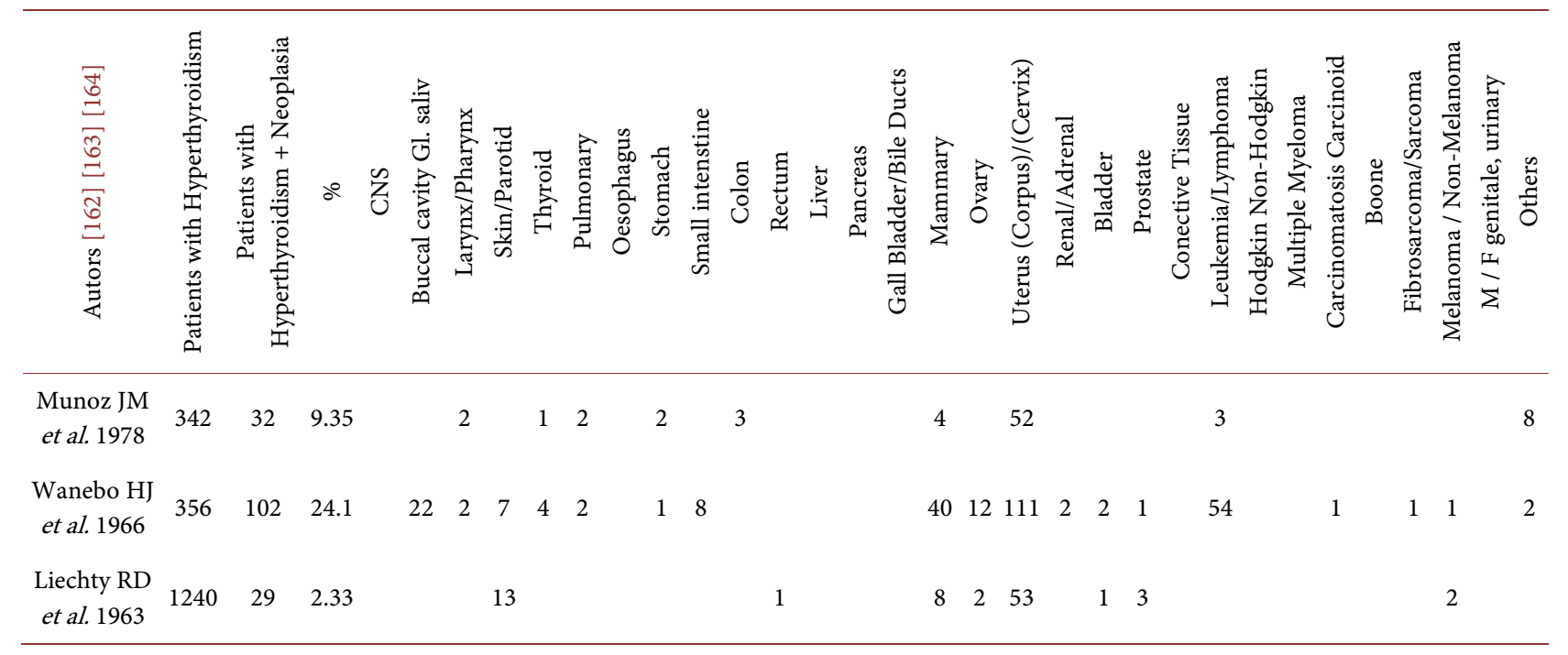

Table 3. Prevalence of malignant tumors in patients with (acromegaly + hyperthyroidism).

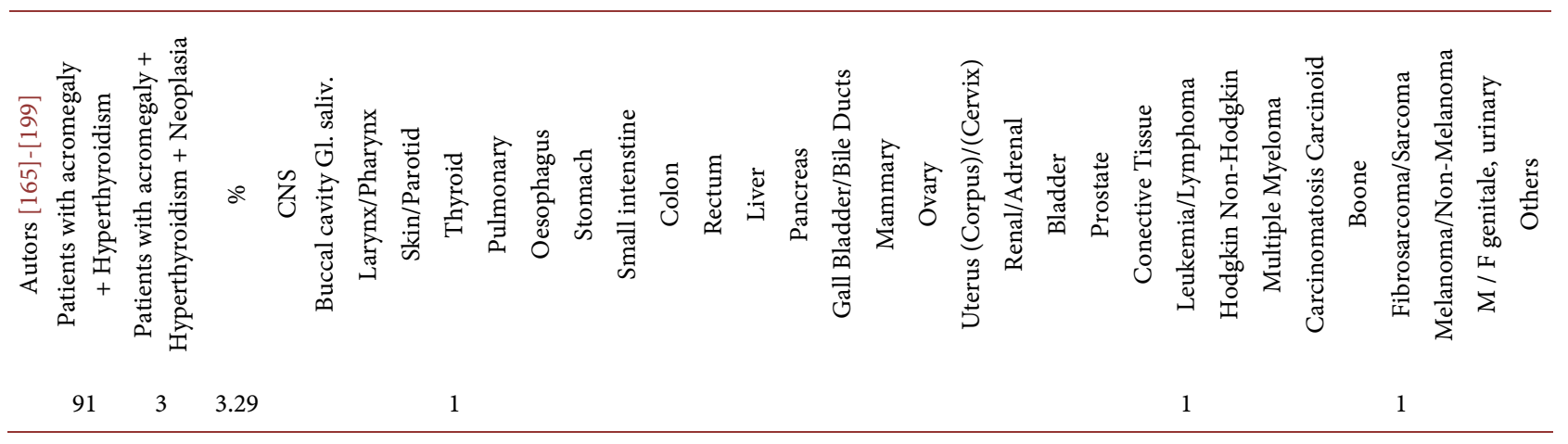

with $9.25 \%$ and of hyperthyroidism alone with $8.44 \%$. But the opposite occurs as the calculation of odds has shown. This may be the result of contrary interactions between altered genomic information flows which run in opposite directions and take the form of interference or shear effects.

\section{Discussion}

The International Herald Tribune of March 2005 reported on a huge project aimed at fighting cancer in order to stimulate interest in the search for the Achilles heel of tumors: "Knowing the defects of the cancer cells points you to the Achilles' heel of tumors" [200], whereby it could not be ruled out that this would have an influence on the orientation of the direction of research.

The habitat plays an important role in explosive speciation. "If the living conditions in such habitats permit, the populations will grow very quickly. When the habitat is filled, such an expansion can lead to a collapse" [201]. Essentially, the enlargement of a population is based on cell proliferation. In this respect, the tumor cells, as cells of unregulated autonomous growth, depend on a habitat and this is, in this case, the tumor-bearing organism. The loss of function of the tu- 
mor suppressor organs resulting from mutations leads to an increasing tumor cell proliferation, from which it can be concluded that the tumor suppressor organs act as a dam.

This "dam" ensures, in the sense of an interpretation, the separation between the controlled growth cells as a dynamic state and the uncontrolled autonomous growth cells as a kinetic state. This leads to the conclusion that an autochthonous proliferation dynamic must be anchored in each individual cell, namely in the sense of a proliferation enthalpy and with zero nutrition as an absolute zero point.

"A mutation in one cell, or a stem cell, would give it a slight growth advantage. One of the progeny cells would then undergo a second mutation that would allow its descendants to grow more uncontrollably and form a small benign tumor; A third mutation in a cell with this tumor would allow it to outgrow the others and the constraints of the tumor microenvironment, and its progeny would form a mass of cells, each of which would have these three mutations. An additional mutation in one of these cells would allow its progeny to escape into the bloodstream and establish the colonies at other sites, the hallmark of metastatic cancer" [202].

From this it can be seen that the cells from the previous mutation form the prerequisite for the next mutation and that the corresponding proliferation would follow after a mutation. The function loss of the gene p53 leads to an accumulation of additional higher speed mutations [203]. One thus has the impression that the proliferation precedes the mutation in the case of ever-increasing speeds.

From this point of view, the function loss of gene p53 occurs after the "benign tumor stage". In this case, the tumor cells which belong to the unregulated autonomous growth cells have no resemblance to the mother tissue from which they originated. They are classified by the local cells as non-local cells and trigger a confrontation. There is a positive correlation between growth rate, malignancy and magnitude of aerobic glycolysis [88]. This is absent in the aerobic glycolysis of normal tissues, e.g. retina, kidneys, leukocytes [204].

After the second mutation, a benign tumor [202] develops. "In some such benign tumors, there is virtually no danger of them becoming malignant, but in others, e.g. polyps that can develop in the intestinal wall are very likely to produce, sooner or later, cells that cross the border from the benign to malignant state" [205].

The intestinal polyps are subjected to friction resistance during the movement of the intestinal contents. This could lead to destructive changes of the polyps contained in the benign tumor cells. Cell debris resulting from cell destruction forms a feeder layer that accelerates cell proliferation [79]. The fact that the benign cell malignant degeneration increases with the size of a polyp [206] supports this reasoning.

The finding that in some benign tumors "there is almost no danger that they become malignant" means that there can also be virtually no mutations. This 
leads to the suspicion that parallel to the mutation rail, in which the development of a benign tumor takes place, there is also another mutation rail, in which the benign "status" is bypassed. In this regard, please refer to (R.S. Cotran et al.).

"Traditionally, the presence of clonal karyotypic abnormalities has been associated with malignant transformation. The challenge now is to determine the significance of karyotypic abnormalities in benign neoplasms. Do they represent one of the several steps involved in malignant transformation, or are they secondary abnormalities in cells that are genetically unstable?” [26].

Neoplasia is considered to be a "reprogramming of the gene expression in neoplastic cells, ... experimental results point at any rate to" ... close relationship between most enzymatic changes to the growth rate (progression-linked), ... and "the occurrence of very early aberrations during carcinogenesis of the carbohydrate metabolism, which may be closely related to the later formation of aerobic glycolysis" [204].

The positive correlation between growth rate, malignancy, size of aerobic glycolysis and the increase in the activity of the (corresponding) enzymes in the respective tumor cells [88] as well as the positive correlation between degree of malignancy and degree of differentiation [21] and their dependence on lactate production [19], can be depicted by a circular function:

The growth rate of the tumor cells increasingly requires a glycolytic supply of energy, which provokes an increase in the glycolysis. This leads to an increase in lactate production. This, in turn, results in a further reduction of the degree of differentiation and thus an increase in cell proliferation. The is due to there being an inverse correlation between lactate production and differentiation as well as an inverse correlation between differentiation and proliferation [19], [89] which, in turn, requires more glycolytic energy. From this point of view, there is a circular process "driven" by mutual acceleration of proliferation and glycolysis, which ultimately leads to the formation of a spiral of morphofunctional destructions (malignity spiral). This probably blocks the cells from maturing further.

The successive mutations, or the functional losses, of the analogous genes represent a linear movement, whereas the mutual acceleration of proliferation and glycolysis corresponds to a pendulum motion.

This is similar to the movement of a cyclist. The cyclist pedals alternately left then right. Pressing down the left pedal e.g. corresponds to cell proliferation, whilst pressing down the right pedal corresponds to the magnitude of the glycolysis. The "de-differentiation scale" is "rolled out" during the forward movement of the cyclist.

From this point of view, the rate of "de-differentiation" is determined by the mutual acceleration of proliferation and glycolysis, and, with respect to "higher speeds", is consistent with:

“... the p53 function loss probably allows the degenerate cells not only to bypass the apoptosis and split, but also to accumulate additional mutations at high speed" [203]. 
It is unlikely that a mutation, as a chance hit, could accelerate the occurrence of the next chance hit. This leads to the assumption that the cell proliferation of the mutation precedes the function loss of gene p53 in the case of accelerating successive mutations. This is due to the fact that glycolysis, which is positively correlated with proliferation [88], has the ability to accelerate itself. The nucleotide DPN (diphosphopyridine nucleotides) generated by the glycolysis has the ability, in the unbound form, to accelerate the glycolysis in the tumor cells [207].

From this point of view, it can be assumed, in the sense of a hypothesis that, after the p53 function loss, the positive correlation processes are transferred to an "acceleration rail". The sequence of the mutations would be, in this sense, the projection of the "de-differentiation scale", whereby the function loss of a gene reflects the projection of the corresponding stage of the "de-differentiation scale". Thus, in the case of the induction of a differentiation, the "de-differentiation scale" and hence its projections could be "rolled up". If not, reversibility in the sequence of the mutations would have to be assumed.

\section{From the Transformed Cell to the Homeostatic Disorder}

According to a biology model on catastrophe theory, death can occur through two different mechanisms: loss of homeostatic controls or the loss of sufficient free energy [208]. Due to the fact that the tumor disease is a semi-catabolism, the loss of the homeostatic controls is to be seen as the cause. In this respect, homeostatic disorder represents the final stage of malignancy, beginning with a reduction in the degree of differentiation.

The reprogramming of the gene expression leads to the formation of the neoplastic cells (204). Confrontation of these with the local cells, results in provoking the malignancy which leads to the development of the disease.

"However, the malignant properties resulting from the transformation are not recognizable in the tissue culture, but rather are revealed only after reimplantation of cells into the experimental animal organism" [1].

"The in vivo absorptive capacity of the tumor is limited by the relatively small, and mainly peripheral, supply of the tumor" [5]. In order to tap into a feeder layer, it is to be assumed that the implanted tumor cells are forced into a confrontation course by the supply bottleneck which they find themselves in. This causes them to develop a higher malignancy which is positively correlated with the growth rate and the magnitude of the glycolysis [88].

From this point of view, the malignancy consists of two components on the basis of a diminishing differentiation:

1) The mechanical component that underlies the invasion. According to this, the tumor cells exhibit incomplete to missing constructions of junction complexes, characterized by sharp tips pointing in the invasive direction [7]. This allows the tumor cells, under the pressure of an increasing proliferation, to destructively displace the normal cells (destructive invasion).

2) The enzymatic component which aims at using the skeletal muscle degra- 
dation, releasing amino acids at the same time, as an instrument to achieve a homeostatic disorder.

With respect to 1 . If the cells of the unregulated autonomous growth have no resemblance to the tissue from which they originated, they are classified as non-local by the local cells, which ultimately leads to a confrontation between the two. These malignant cells have a reduced degree of differentiation. If these cells leave the primary tumor later to form metastases, the degree of differentiation with respect to the primary tumor is (further) reduced [1].

During their growth, malignant tumors have a high glycolysis rate, producing large amounts of lactic acids [79]. On the basis of the inverse correlation between lactate production and differentiation [19] and the inverse correlation between proliferation and differentiation [89], a positive correlation exists between proliferation and lactate production. However, this is determined by the rate at which the product (lactate) is removed [86]. This shows that the positive correlations between the rate of proliferation, the magnitude of the glycolysis and the malignancy are dependent on the intracellular/extracellular lactate gradient. Inhibition of the development of metastasis in cirrhotic livers [81] and the increase of glycolysis in the case of HCC [84] support this.

"The degree of differentiation of the metastases is reduced compared to the cells of the primary tumor" [1]. In the context of the findings that $90 \%$ of the outcome of the disease is determined by the metastases [22], and that "in the majority of patients who have been operated on or have received chemotherapy treatment because of their liver metastases, the disease determines the prognosis outside the liver" [209], points to the effects of a diminishing differentiation that influences the tumor-bearing organism in its entirety.

With respect to 2 . With the presence of a tumor, there is a forced catabolism of the skeletal muscle, which leads to the release of amino acids [23]. The pattern of amino acid concentrations in the plasma or serum in the case of a deficiency diet (i.e., after passing through the control mechanisms of the intestine and the liver) differs from that of carcinoma patients [23]. There is an imbalance in the concentrations of the amino acids in the plasma of tumor patients [25], which indicates an impairment of the liver control mechanisms. Such a situation would lead to pathological changes in normal cells and to a homeostatic disorder [24].

If the degradation of the skeletal muscle is induced by an enzyme from the tumor cells, this should correspond to the reduced degree of differentiation of the tumor cells. The enzyme pattern of well-differentiated neoplastic cells hardly differs from that of the corresponding normal cells [26]. This indicates a change in the enzyme pattern with decreasing degree of differentiation. In contrast to a benign tumor [2], there is the forced degradation of the skeletal muscle in the presence of a malignoma [23]. From this point of view, this is probably due to enzymes which correspond to the respective degree of tumor cell diminishing differentiation and determine the aggressiveness of the skeletal muscle degradation. Consequently, the skeletal muscle degradation constitutes an "interlacing" between diminishing differentiation and increasing homeostatic disorder, i.e. it 
represents the continuity of the pathomechanism.

Grabbing energy from the skeletal muscle by the malignant cells supports this. "Cancer Usurps Skeletal Muscle as an Energy Repository" [210]. In contrast to benign tumor cells, only the malignant cells can achieve this, which suggests that pre-damage of the skeletal muscle by tumor enzymes is the prerequisite for this. Accordingly, an inhibition of the degradation of the skeletal muscle should lead to an anticancer effect.

Infusion of a triglyceride emulsion leads to an inhibition of muscle degradation [211]. Hypertriglyceridaemia leads to a significant prolongation of the survival time in tumor patients.

"Bexarotene was evaluated in treating advanced non-small cell lung cancer (NSCLC) in two-phase III trials. (617 patients), a third of bexarotene-treated patients who developed high-grade hypertriglyceridemia exhibited significantly longer survival" [212], also [213] [214]. In addition, animal experiments have shown that "ketone supplementation decreases tumor cell viability and prolong survival of mice with metastatic cancer" [215], which is also due to the inhibition of muscle breakdown by ketone bodies [216].

The prolongation of the survival time corresponds to a delay in the development of the general disease, i.e. it is an inhibitory intervention in the pathomechanism.

Numerous publications refer to an anticancer effect resulting from training.

"Regular and vigorous physical exercise has been scientifically established as a strong preventive medicine against cancer with the potential to reduce incidence by $40 \% "$ [217].

This is probably due to an inhibition of the degradation of the skeletal muscle and seems to depend on the leukemia-inhibitory factor.

The leukemia inhibitory factor enhances muscle repair in vivo [218] and exercise induces expression of leukemia inhibitory factor in human skeletal muscle [219].

When a tumor is present, there is a forced catabolism of the skeletal muscle [23], which is said to be enzymatic. The inhibition of the degradation leads to a significant delay in the development of the disease [212], which indicates a blocking of the enzyme. This leads to the suggestion that inactivation of this enzyme could yield more efficient results.

As described above, the $S$. sanguinis enzyme arylaminopeptidase is capable of inactivating an enzyme in connection with an endocarditis as a source of infection, resulting in a relatively low accumulation of malignomas. By comparison, there is a relatively high accumulation of malignomas in an inactivated arylaminopeptidase ( $S$. sanguinis bacteremia without endocarditis).

This leads to the question whether the arylaminopeptidase is capable of inactivating the enzyme which degrades the skeletal muscle. If this were not the case, then, along with the inhibition of tumor development due to an active arylaminopeptidase, the tumor-related degradation process of the skeletal muscle would have to continue. These two dynamic states are mutually exclusive. 


\section{Variability of Malignancy}

In the case of extrapancreatic tumors (summary of 180 cases by different authors) with hypoglycemia, no elevated serum insulin level or insulin-like activities were detected. These tumors do not belong to a single type, they grow slowly, do not develop any metastases, and may reappear at the same place after surgical removal [220].

One explanation for this could be the impoverishment of glycolytically provided energy. It would inhibit ATP depletion caused by glycolysis in microenvironment, which could lead to stabilization of the gap junctional complexes which would ultimately lead to inhibition of the spreading of tumor cells on the invasion front, i.e. in the sense of an inversion [8], [9], [10]. It could be formulated as follows: In the case of a glycolysis inhibition, the malignant cells are forced to retract their "claws". In this way, the malignant cells could be transferred from the state of invasive cell proliferation to the state of a circumscribed proliferation without invasiveness that could possibly lead to a transformation of malignant tumors into benign tumors.

\section{Asymmetric Catabolism}

Malignoma patients are affected asymmetrically by the catabolism, and there is proteolysis dominance in the periphery as well as protein synthesis in visceral organs [23]. In the case of some of the visceral organs the percentage quantity is hardly altered, whilst others show an increase [221]. This condition can be characterized as asymmetric catabolism, which seems to be advantageous for the tumor.

The fact that the visceral organs cannot be detected in asymmetric catabolism indicates an increased functional stress on these organs. This is likely associated with the increased glucose requirements of the tumor cells, and this should be provided by gluconeogenesis. It is known that the liver and kidney have gluconeogenesis capability, but according to recent findings, other visceral organs are said to possess this capability. “... in a variety of organs such as the small intestine, stomach, adrenal gland, testis, and prostate which might also contribute to gluconeogenesis" [222]. "The fact that the periphery of malnourished carcinoma patients releases more amino acids than the periphery of malnourished control subjects without carcinoma" [23], is an indication of an objective of the released amino acids, which extends beyond the significance for gluconeogenesis.

If catabolism occurred, as is the case of long-term fasting, the released amino acids would be used for energy supply to the organism. After a few weeks the degradation of the skeletal muscle would be restricted and a changeover to ketone bodies [223] would occur. These should inhibit the skeletal muscle degradation [216]. A ketogenic diet results in a reduction in tumor growth and an inhibition of muscle and body weight loss [224]. Asymmetric catabolism thus prevents the tumor-bearing organism from slipping into long-term fasting catabolism and can be regarded as a tumor protective mechanism. 


\section{Tumor Cachexia: Starvation with Good Nutrition}

It is contradictory that in the case of a tumor cachexia, restricted nourishment leads to an anticancer effect [225], whilst a good diet does not affect the course of the disease of a tumor-bearing patient [226], even though this would be expected. This leads to the assumption that the nutrients present in a good diet are "wasted".

"Patients with cancer cachexia seem to have higher rates of whole body protein turnover than either non-cancer patients or starved normal subjects. Concomitantly, there is a disproportionately increase rate of metabolism of all nutrients, often accompanied by a reduced food intake that has been related to abnormalities in the sensation of taste and in the central control of appetite ... but one fact is clear cachexia is not caused by nutritional demands of the tumor" [26].

This leads to the suggestion that the tumor cachexia is responsible for a delay in nutrient absorption at the cellular level, which is also supported by the slowed incorporation of amino acids [23], resulting in cellular saturation and subsequent nutrient accumulation which is projected onto the tumor-bearing organism as anorexia. This nutrient accumulation at the cellular level is likely to lead to increased metabolism. This supported by the fact that malignoma patients subjected to parenteral nutrition exhibit an increase in the whole body protein turnover. This, in turn, "indicates that the protein loss cannot be avoided by adequate parenteral diet therapy" [227].

The delay in consumption of nutrients at the cellular level is likely to be due to the effect of the released amino acids apparently bypassing the corrective mechanisms of the liver. The organ-specific characteristic pattern of free amino acids [5] could, consequently, be distorted and cause function impairment of various organs. Similar behavior is to be observed in the tissue culture of case of heart fibroblasts. These heart fibroblasts exhibit growth retardation following the addition of enzymatically degraded tumor proteins compared to the growth rate after the addition of enzymatically degraded proteins from normal tissues [5].

With regard to the significance of the forced catabolism of the skeletal muscle in the presence of a tumor on the development of homeostatic disorder, as pointed out above, it can be concluded that muscular atrophy, which is a hallmark of cancer cachexia [228], should not be regarded as a consequence of cachexia, but rather the cachexia is a result of an increasing, homeostatic disorder, which is initiated by the degradation of the skeletal muscle.

\section{Entvitalization of the Tumor-Bearing Organism}

In some diseases, e.g. cancer, there is a loss of the maintenance of the protein homoeostasis. This can be seen as a consequence of the homoeostatic disorder of the amino acids. "Failure to maintain protein homestasis is associated with aggregation and cell death, and underlies a growing list of pathologies including neurodegenerative diseases, aging and cancer" [229]. In this context, it should be mentioned that: "The question of whether the presence of a tumor affects the 
whole organism is of great clinical importance" (Rapoport SM 1965) [230].

This leads to the question of on which basis the entvitalization of the tumor-bearing organism occurs. According to a biology model of catastrophe theory, death can occur by two different mechanisms: Loss of homeostatic controls or loss of sufficient free energy.

“... in which death can occur by two distinct mechanisms: loss of homeostatic control or loss of adequate free energy" [208].

Considering that tumor patients are in a condition of semi-catabolism, there is likely to be no energy problem. A homoeostatic disorder can be assumed as the cause leading to death of tumor patients. In this sense, it can be said that: The tumor patient, even though he has enough energy to reach the shore, drowns in waves of homeostatic disorder.

The thesis that "cancer is a consequence of evolution" [231], leads to J. Monod's thesis on "chance and necessity". "If the individual, and as such essentially unpredictable, event is registered in the DNA structure, then it will be exactly duplicated mechanically and translated ... If the dominance of pure chance is removed, then the domination of necessity makes it an unshakeable certainty" [232]. From this point of view, is cancer dominated by another, still incomplete, necessity?

The conversion of the energy supply from glycolysis to glucose oxidation, induced by dichloroacetate (DCA), causes apoptosis, leads to a reduction in proliferation and inhibits tumor growth [233]. The reduction in proliferation correlates with an increase in differentiation [89]. If the increasing differentiation is equated with increasing order and decreasing differentiation is equated with decreasing order, then it can be concluded from this that the oxidation of glucose leads to a cellular order, whilst glycolysis leads to a cellular disorder in the case of unregulated and autonomous growth cells.

The gain in ATP is 18 times lower than is the case for the oxidative degradation of glucose, which means that the tumor cells find themselves in an energy-related emergency situation [79]. The higher flow of glucose [14] resulting from this can be seen as a result of a suction effect acting on the glucose caused by the energy-related emergency situation of the tumor cells.

It can thus be formulated that the malignant cells have induced their own energy-related emergency situation through uneconomical energy consumption in order to develop destructive dynamics. In doing so, they attempt to feign an exergonic reaction in order to produce disorder, such as e.g. the dissociation of morphogenetically anchored structures and distribution analogies. The question is, have the malignant cells strived to create a disorder in order establish a new order?

From this point of view, it should be in the interest of the transformed cells to keep the tumor-bearing organism alive for a very long time. But the opposite is the case, and this is not the result of the transformed cells alone. An increase in malignancy is provoked as a result of the confrontation between local and non-localized cells, and there is a reduction in the degree of differentiation [1]. 
This shortens the life of the tumor-bearing organism, or that of the habitat of the transformed cells. This leads to the assumption that the tumor-bearing organism had found this program unacceptable and should therefore try to block it. It is not possible to eliminate the tumor cells by apoptosis because the tumor cells can bypass the apoptosis [205]. Thus, the tumor-bearing organism tries to lead itself to an "apoptotic path". To achieve this purpose, it uses the malignancy, and its increase, as an instrument which it produces itself to terminate the realization of the program in a suicidal manner.

It would be expected that fatigue symptoms would gradually occur in the form of a decreasing cancer frequency occurrence.

"Following decades in which the number of deaths rose strongly, the absolute number of cancer deaths has hardly increased (men) or decreased (women)" in recent years [234].

Cancer itself could put it this way: I have been called invincible [235]; I have caused countless suffering for a great many people, now I am gradually withdrawing. Nevertheless, I have created lots of jobs and helped many to achieve fame and great wealth.

\section{Conclusions}

The initiation of neoplastic cells by the reprogramming of the gene expression and the tumorogenic degradation of the skeletal muscle, which transforms the decreasing differentiation into an increasing homeostatic disorder, are the two main processes of the pathomechanism.

1) The strikingly low incidence of malignomas (inhibition in the occurance of malignomas) versus the expected higher levels is due to an interference or shearing effect of two opposing genomic information flows. An interaction between increased anabolism and an increased catabolism provides an explanation for this low level.

2) The low malignancy (inhibition of the development of malignomas) is due to the inhibition of the tumorogenic degradation of the skeletal muscle through the inactivation of the tumor enzyme. The inactivation of this enzyme is effected by an enzyme from the $S$. sanguinis, and depends on an endocarditis as a source of infection.

\section{Acknowledgements}

I would like to express my thanks and appreciation to Gerald Parker for translating the original German text into English.

\section{Conflicts of Interest}

The author declares no conflicts of interest regarding the publication of this paper.

\section{References}

[1] Holle, G. (1989) Pathologie des unregulierten, autonomen Wachstums. Gutartige 
Tumoren und maligne Neiplasien. In: Holle, G., Ed., Allgemeine Pathologie, 2nd Edition, G. Fischer, Stuttgart, 426-491.

[2] Grundmann, E. (1996) Tumoren. In: Grundmann, E., Ed., Einführung in die Allgemeine Pathologie, $9^{\text {th }}$ Edition, G. Fischer Verlag, Stuttgart, 152-194.

[3] Schmähl, D. (1981) Die Metastasierung. In: Schmähl, D., Eisenbrand, G. and Fiebig, H.H., Eds., Maligne Tumoren, Arzneimittel-Forschung, Editio Cantor, Aulendorf, 364-393.

[4] Büchner, F. (1962) Die Pathologie des Eiweißstoffwechsels. In: Büchner, F., Ed., Allgemeine Pathologie, 92.

[5] Dannenberg, H. (1959) Die Biochemie der Tumoren. In: Flaschenträger, B. And Lehnartz, E., Eds., Physiologische Chemie, Bd. 2, Teil 2, Bandteil C. Springer-Verlag, Berlin, 342-460.

[6] Gabbert, H.E. (1989) Basismechanismen der Metastasierung. In: Rothmund, M., Ed., Metastasenchirurgie, G. Thieme Verlag Stuttgart, New York, 3-16.

[7] Gabbert, H. (1984) Invasionsmechanismen maligner Tumoren (Mechanisms of Tumorinvasion). Verh.Dtsch.Ges.Path., 68, 18-32.

[8] Lotz, C., Kelleher, D.K., Gassner, B., Gekle, M., Vaupel, P. and Thews, O. (2007) Role of the Tumor Microenvironment in the Activity and Expression of the P-Glycoprotein in Human Colon Carcinoma Cells. Oncology Reports, 17, 239-244. https://doi.org/10.3892/or.17.1.239

[9] Brèzillon, S., Zahm, J.M., Pierrot, D., Gaillard, D., Hinnrasky, J., Millart, H., Klossek, J.M., Tümmler, B. and Puchelle, E. (1997) ATP Depletion Induces a Loss of Respiratory Epithelium Functional Integrity and Down-Regulates CFTR (Cystic Fibrosis Transmembrane Conductance Regulator) Expression. Journal of Biological Chemistry, 272, 27830-27838. https://doi.org/10.1074/jbc.272.44.27830

[10] Ikejima, K., Watanabe, S., Kitamura, T., Hirose, M., Mayazaki, A. and Sato, N. (1995) Hepatocyte Growth Factor Inhibits Intercellular Communication via Gap Junctions in Rat Hepatocytes. Biochemical and Biophysical Research Communications, 214, 440-446. https://doi.org/10.1006/bbrc.1995.2306

[11] Dvorak, H.G. (1986) Tumors: Wounds That Do Not Heal. Similarities between Tumor Stroma Generation and Wound Healing. New England Journal of Medicine, 315, 1650-1659. https://doi.org/10.1056/NEJM198612253152606

[12] Wagner, C. and Müller, O. (2010) Molekulare Onkologie. $3^{\text {th }}$ Edition, Georg Thieme Verlag Stuttgart, New York, 329. https://doi.org/10.1055/b-002-10334

[13] Dargel, R. (1995) Das Phänomen Entzündung. In: Dargel, R., Ed., Entzündung, Ulstein Mosby, Berlin, Wiesbaden, 1-8.

[14] Hofmann, E. (1986) Zellbiochemie. In: Hofmann, E., Ed., Dynamische Biochemie Teil III, Akademie-Verlag, Berlin, 22.

[15] Feng, L., Sun, X., Csizmadia, E., Han, L., Bian, S., Murakami, T., Wang, X., Robson, S.C. and Wu, Y. (2011) Vascular CD39/ENTPD1 Directly Promotes Tumor Cell Growth by Scavenging Extracellular Adenosine Triphospate. Neoplasia, 13, 206-216. https://doi.org/10.1593/neo.101332

[16] Weiss, L. (1985) Priciples of Metastasis. Academic Press, Orlando.

[17] Heberer, G., Rau, G. and Löhr, H.-H. (1966) Physiologie des Kreislaufes und der Gefäße. In: Heberer, G., Ed., Aorta und große Arterien, Springer-Verlag, Berlin Heidelberg, New York, 17-56. https://doi.org/10.1007/978-3-642-49155-9_2

[18] Voet, D. and Voet, J.G. (1992) Biochemistry. John Wiley \& Sons, Hoboken.

[19] Zweibaum, A., Pinto, M., Chevalier, G., Dussaulx, E., Triadou, N., Lacroix, B., Haf- 
fen, K., Brun, J.L. and Rosset, M. (1985) Enterocytic Differentiation of a Subpopulation of the Human Colon Tumor Cell Line HT-29 Selected for Growth in Sugar-Free Medium and Its Inhibition by Glucose. Journal of Cellular Physiology, 122, 21-29. https://doi.org/10.1002/jcp.1041220105

[20] Wu, H., Scher, B.M., Chu, C.L., Leonard, M., Olmedo, R., Scher, G.S., Stecker, S., Scher, W. and Waxman, S. (1991) Reduction in Lactate Accumulation Correlates with Differentiation-Induced Terminal Cell Division of Leukemia Cells. Differentiation, 48, 51-58. https://doi.org/10.1111/j.1432-0436.1991.tb00242.x

[21] Müller-Hermelink, H.K. and Müller, J.G. (2000) Morphologische Diagnostik. In: Wilmanns, W., Huhn, D. and Wilms, K., Eds., Internistische Onkologie 2. Auflage Stuttgart, Thieme, New York, 2-28.

[22] Grundmann, E. (1981) Das Wesen des Malignen Wachstums (Mechanism of Malignant Growth). Klinische Wochenschrift, 59, 931-941. https://doi.org/10.1007/BF02310968

[23] Holm, E., Schimpf, F., Schlickeiser, G.G., Söhner, W., Staedt, U. and Striebel, J.P. (1987) Aminosäurenstoffwechsel bei Tumorkrankheiten. In: Sauer, R. and Tiel, H.J., Eds., Ernährungsprobleme in der Onkologie. Aktuelle Onkologie 35, Zuckschwerdt Verlag, München, 25-54.

[24] Grünert, A., Engels, J., Seewald, U., Dölp, R. and Ahnefeld, F.W. (1984) Parenteral Administration of Amino Acids, Reference Values-Study Technic-Interpretation of the Study Results-Amino Acid Pattern as a Criterion of the Regulation of Homeostasis. Infusionstherapie und Klinische Ernahrung, 11, 12-25.

[25] Selberg, O., Weimann, A. and Müller, M.J. (1991) Genese der Tumorkachexie. In: Schauder, P., Ed., Ernährung und Tumorerkrankungen, Karger, Basel, 198-212. https://doi.org/10.1159/000420260

[26] Contran, R.S., Kumar, V. and Robbins, S.L. (1989) Neoplasia. In: Pathologic Basis of Desease, 4th Edition, Saunders E.B., Philadelphia, 239-305.

[27] Simon, C. und Stille, W. (1989) Antibiotika-Therapie in Klinik und Praxis 7. Auflage-Stuttgart. Schattauer, New York, 570.

[28] Awada, A., van der Auwera, P., Meunier, F., Daneau, D. and Klastersky, J. (1992) Streptococcal and Enterococcal Bacteremia in Patients with Cancer. Clinical Infectious Diseases, 15, 33-48. https://doi.org/10.1093/clinids/15.1.33

[29] Yamaguchi, M., Terao, Y., Ogawa, T., Takahashi, T., Hamada, S. and Kawabata, S. (2006) Role of Streptococcus sanguinis Sortase A in Bacterial Colonization. Microbes and Infection, 8, 2791-2796.

[30] Cowman, R.A. and Baron, S.S. (1991) Studies on the Subcellular Localization of Protease and Arylaminopeptidase Activities in Streptococcus sanguis ATCC 10556. Journal of Dental Research, 70, 1508-1515. https://doi.org/10.1177/00220345910700120701

[31] Asseray, N. (2008) The Role of Antibiotic-Therapy Referral in Therapeutic Innovation. Apropos of a Case of Streptococcal Endocardititis. Médecine et Maladies Infectieuses, 38, 7-9. https://doi.org/10.1016/S0399-077X(08)75152-7

[32] Kasivisvanathan, V., Levine, A., Kasivisvanathan, R., Brown, D.F. and Nadel, E.S. (2009) Dyspnea and Multiple Pulmonaty Nodules. Journal of Emergency Medicine, 37, 300-304. https://doi.org/10.1016/j.jemermed.2009.07.030

[33] Attias, D., Messika-Zeitoun, D., Wolf, M., Lepage, L. and Vahanian, A. (2008) Acute Coronary Syndrome in Aortic Infective Endocarditis. European Journal of Echocardiography, 9, 727-728. 
[34] Nyawo, B., Shoaib, R.F., Evemy, K. and Clark, S.C. (2007) Infective Endocarditis during Pregnancy: Case Report. The Heart Surgery Forum, 10, E480-E481. https://doi.org/10.1532/HSF98.20071119

[35] Bavunoglu, I., Sahin, S., Yilmaz, M., Toptas, T., Tabak, F. and Tunckale, A. (2007) Native Triple-Valve Endocarditis Caused by Penicillin-Resistant Streptococcus sanguis. Nature Clinical Practice Cardiovascular Medicine, 4, 340-343. https://doi.org/10.1038/ncpcardio0906

[36] Rega, F.R., Nevelsteen, A., Peetermans, W.E., Herregods, M.C., Flameng, W. and Herijgers, P. (2006) Simultaneous Valve Replacement and Venous Patch Repair of Superior Mesenteric Artery Aneurysm Due to Infective Endocarditis: A Case Report. The Heart Surgery Forum, 9, E741-F743.

https://doi.org/10.1532/HSF98.20061029

[37] de Diego, C., Marcos-Alberca, P. and Pai, R.K. (2006) Giant Periprosthetic Vegetation Associated with Pseudoaneurysmal-Like Rupture. European Heart Journal, 27, 912. https://doi.org/10.1093/eurheartj/ehi540

[38] Maliaga, A., Mintzias, D., Zigouris, N., Kappou-Rigatou, I. and Skoutelis, A. (2006) Bacterial Endocarditis with Dual Presentation as Endophthalmitis and Glomerulonephritis. European Journal of Internal Medicine, 17, 125-126. https://doi.org/10.1016/j.ejim.2005.09.019

[39] Shin, G.Y., Manuel, R.J., Ghori, S., Brecker, S. and Breathnach, A.S. (2005) Molecular Technique Identifies the Pathogen Responsible for Culture Negative Infective Endocarditis. Heart, 91, e47. https://doi.org/10.1136/hrt.2004.056762

[40] Bhattacharyya, S., Hickman, M. and Lythall, D. (2005) Mitral Valve "Kissing" Vegetation. Heart, 91, e43. https://doi.org/10.1136/hrt.2004.056713

[41] Calleja Subiran, M.C. and Taboada Vilarino, F. (2005) Bacterial Endocarditis in an Adult on the Interventricular Septal Congenital Defect. Anales de Medicina Interna, 22, 47-49.

[42] Monniert, G., Guerard, S., Caignault, J.R., Godon, P., Van de Walle, J.P. and Brion, R. (2000) Isolated Primary Streptococcal Tricuspid Endocarditis. A Case Report. Annales de Cardiologie et d Angéiologie (Paris), 49, 403-406.

[43] Raval, A.N., Menkis, A.H. and Boughner, D.R. (2002) Mitral Valve Aneurysm Associated with Aortic Valve Endocarditis and Regurgitation. The Heart Surgery Forum, 5, 298-299.

[44] Setty, S.P., Milsom, F.P. and Armstrong, G. (2002) Asymmetric Primary Ringless Repair of Mitral Valve Endocarditis; a Case Report. The Journal of Heart Valve Disease, 11, 292-295.

[45] Laguno, M., Miro, O., Font, C. and de la Sierra, A. (1998) Pacemaker-Related Endocarditis. Report of 7 Cases and Review of the Literature. Cardiology, 90, 244-248. https://doi.org/10.1159/000006852

[46] Inada, T., Shirono, K. and Tsuda, H. (1995) Hemolytic Anemia in a Patient with Subacute Bacterial Endocarditis Due to Streptococcus sanguis. Acta Haematologica, 94, 95-97. https://doi.org/10.1159/000203981

[47] Menz, V., Drude, L., Schönian, U., Herzum, M., Bethge, C. and Maisch, B. (1994) Löffler Endocarditis Fibroplastica with Simultaneous Infectious Endocarditis. Herz, 19, 138-143.

[48] Das, S.S., Anderson, J.R., Macdonald, A.A. and Somerville, K.W. (1994) Endocarditis Due to High Level Gentamicin Resistant Enterococcus faecium. Journal of Infection, 28, 185-191. https://doi.org/10.1016/S0163-4453(94)95680-4 
[49] Mecrow, I.K. and Ladusans, E.J. (1994) Infective Endocarditis in Newborn Infants with Structurally Normal Hearts. Acta Paediatrica, 83, 35-39. https://doi.org/10.1111/j.1651-2227.1994.tb12949.x

[50] Mestres, C.A., Ginel, A., Cartana, R. and Pomar, J.L. (1993) Cryopreserved Homografts in Aortic and Mitral Prosthetic Endocarditis; Expanding the Use of Biological Tissues in Complex Cardiac Infections. The Journal of Heart Valve Disease, 2, 679-683.

[51] Read, R.C., Finch, R.G., Donald, F.E., Morris, G.K. and Somerville, J. (1993) Infective Endocarditis after Transesophageal Echocardiography. Circulation, 87, 1426.

[52] Charney, R., Keltz, T.N., Attai, L., Merav, A. and Schwinger, Me. (1993) Acute Valvular Obstruction from Streptococcal Endocarditis. American Heart Journal, 125, 544-547.

[53] Colford, J.M., Corelli, R.L., Ganz, J.W., Guglielmo, B.J. and Jacobs, R.A. (1993) Home Antitiotic Therapy for Streptococcal Endocarditis: A Call for a Controlled Trial. American Journal of Medicine, 94, 111-112. https://doi.org/10.1016/0002-9343(93)90131-8

[54] Chen, M.R. (1992) Infective Endocarditis in Hypertrophic Obstructive Cardiomyopathy. Journal of Clinical Ultrasound, 20, 612-614.

[55] Norfleet, R.G. (1991) Infectious Endocarditis after Fiberoptic Sigmoidoscopy. With a Literature Review. Journal of Clinical Gastroenterology, 13, 448-451. https://doi.org/10.1097/00004836-199108000-00017

[56] Pentimone, F., Del Corso, L., Borelli, A., Riccioni, S. and Salvatore, L. (1991) Destructive Endocarditis Caused by Streptococcus sanguis on Normal Valves after Gastroduodenoscopyl. Minerva Cardioangiologica, 39, 245-249.

[57] Mestres, C.A., Martinez, A., Cartana, R. and Pomar, J.L. (1991) An Alternative Approach in the Surgical Treatment of Infectious Endocarditis. The Fresh Antibiotic-Sterilized Aortic Valve Homograft. Revista Española de Cardiología, 44, 273-276.

[58] Rao, M., John, G., Ganesh, A., Jose, J., Lalitha, M.K. and John, L. (1990) Infective Endocarditis Due to Streptococcus sanguis I Occurring on a Normal Mitral Valve. Journal of the Association of Physicians of India, 38, 866-868.

[59] Foster, E., Kusumoto, F.M., Sobol, S.M. and Schiller, N.B. (1990) Streptococcal Endocarditis Temporally Related to Transesophageal Echocardiography. Journal of the American Society of Echocardiography, 3, 424-427. https://doi.org/10.1016/S0894-7317(14)80145-4

[60] Tunick, P.A., Fox, A.C., Culliford, A., Levy, R. and Kronzon, I. (1990) The Echocardiographic Recognition of an Atrial Myxoma Vegetation. American Heart Journal, 119, 679-680. https://doi.org/10.1016/S0002-8703(05)80297-2

[61] Kerr, K.G. (1989) Low Back Pain as the Only Presenting Symptom in Streptococcus sanguis Endocarditis. Reviews of Infectious Diseases, 11, 836-837. https://doi.org/10.1093/clinids/11.5.836

[62] Stein, D.S. and Libertin, C.R. (1989) Molecular Analysis of Viridans and Nutritionally Deficient (Variant) Streptococci Causing Sequential Episodes of Endocarditis in a Patient. American Journal of Clinical Pathology, 91, 620-624. https://doi.org/10.1093/ajcp/91.5.620

[63] Decroly, P., Vandenbossche, J.L. and Englert, M. (1989) Anterior Mitral Valve Aneurysm Perforation Secondary to Aortic Valve Endocarditis Detected by Doppler Colour Flow Mapping. European Heart Journal, 10, 186-189. 
https://doi.org/10.1093/oxfordjournals.eurheartj.a059461

[64] Logan, R.F. and Hastings, J.G. (1988) Bacterial Endocarditis: A Complication of Gastroscopa. British Medical Journal (Clinical Research Ed.), 296, 1107. https://doi.org/10.1136/bmj.296.6629.1107

[65] Boennig, D.A., Nelson, L.P. and Campos, J.M. (1988) Relatively Penicillin-Resistant Streptococcus sanguis Endocarditis in an Adolescent. The Pediatric Infectious Disease Journal, 7, 205-207. https://doi.org/10.1097/00006454-198803000-00016

[66] Yee, J. and McAllister, C.K. (1987) The Utility of Osler's Nodes in the Diagnosis of Infective Endocarditis. Chest, 92, 751-752. https://doi.org/10.1378/chest.92.4.751

[67] Myles, P.S. (1987) Septic Discitis as a Presentation of Endocarditis. The Medical Journal of Australia, 146, 656-657.

[68] Young, S.G., Davee, T., Fierer, J. and Morey, M.K. (1987) Streptococcus sanguis II (Viridans) Prosthetic Valve Endocarditis with Myocardial, Splenic and Cerebral Abscesses. Western Journal of Medicine, 146, 479-481.

[69] Tucker, R.M., Scheld, W.M., Mentzer, R.M. and Gibson, R.S. (1987) Fatal Multivalvular Endocarditis Due to Streptococcus milleri and Streptocossus sanguis. European Journal of Clinical Microbiology, 6, 214-215. https://doi.org/10.1007/BF02018222

[70] Murata, T., Fujino, M., Sasaki, J., Takii, M. and Arakawa, K. (1987) Right Atrial Vegetation in Left Ventricular-Right Atrial Communication. Clinical Cardiology, 10, 61-62. https://doi.org/10.1002/clc.4960100114

[71] Rhodes, L.E. and Haboubi, N. (1986) Infective Endocarditis Presenting with Back Pain and Stroke. Journal of Infection, 12, 184-185. https://doi.org/10.1016/S0163-4453(86)93858-2

[72] Hackett, D., Nihoyannopoulos, P., Weston, C. and Oakley, C.M. (1985) Myocardial Depression and Nephrotic Syndrome in Streptococcus sanguis Endocarditis. Quarterly Journal of Medicine, 57, 867-873.

[73] Elian, D., Hassin, D., Tomer, A., Bank, H. and Eeisenstein, Z. (1984) Spinal Epidural Abscess: An Ususual Complication of Bacterial Endocarditis. Infection, 12, 258-259. https://doi.org/10.1007/BF01645954

[74] Weinberg, M.S., Ellis, C.A. and Levy, S.B. (1980) Nutritionally Deficient Streptococcus: Investigation of the Hidden Culprit in Culture-Negative Endocarditis. The Southern Medical Journal, 73, 1647-1649. https://doi.org/10.1097/00007611-198012000-00035

[75] McCarty, V.P., Cho, C.T., Diehl, A.M. and Ramsey, B.W. (1979) Bacterial Endocarditis Due to Penicillin-Resistant Streptococcus Viridans. Clinical Pediatrics, 18, 263-266.

[76] Whittington, B.R. (1979) Bacterial Endocarditis: A Clinical Report. New Zealand Dental Journal, 75, 39-43.

[77] Alexandra, S. (1997) Lactatschwellen in Ernährungswissenschaftliche Schriften (Disser). Wissenschaftlicher Fachverlag Giessen 6-7.

[78] Fischer, K., Hoffmann, F., Voelkl, S., Meidenbauer, N., Ammer, J., Edinger, M., Gottfried, E., Schwarz, S., Rothe, G., Hoves, S., Renner, K., Timischl, B., Mackensen, A., Kunz-Schughart, L., Andreesen, R., Krause, S.W. and Kreutz, M. (2007) Inhibitory Effect of Tumor Cell-Derived Lactic Acid on Human T Cells. Blood, 109, 3812-3819. https://doi.org/10.1182/blood-2006-07-035972

[79] Riede, U.N., Rohrbach, R., Adler, C.P., Sandritter, W., Thomas, C. and Mittermayer, C. (1986) Störungen des Wachstums. In: Sandritter, W., Ed., Allgemeine Pathologie, 
2, Schattauer, Stuttgart, 589-716.

[80] Buddecke, E. and Fischer, M. (1992) Pathophysiologie, Pathobiochemie, Klinische Chemie. de Gruyter, Berlin, New York, 105.

[81] Schmähl, D. (1989) Die Metastasierung. In: Schmähl, et al., Eds., Maligne Tumoren. Arzneimittel-Forschung, Editio Contor Aulendorf, 21, 364-393.

[82] Woll, P.J. and Record, C.D. (1979) Lactate Elimination in Man: Effects of Lactate Concentration and Hepatic Dysfunction. European Journal of Clinical Investigation, 9, 397-404. https://doi.org/10.1111/j.1365-2362.1979.tb00903.x

[83] Noltenius, H. (1987) Pathologie und Klinik der menschlichen Tumoren. 2nd Edition, München-Wien-Baltimore, Urban u. Schwarzenberg, Bd. 1, 389.

[84] Chan, I.S., Guy, C.D., Chen, Y., Lu, J., Swiderska-Syn, M., Michelotti, G.A., Karaca, G., Xie, G., Krüger, L., Syn, W.K., Anderson, B.R., Fereira, T.A., Choi, S.S., Baldwin, A.S. and Diehl, A.M. (2012) Paracrine Hedgehog Signaling Drives Metabolic Changes in Hepatocellular Carcinoma. Cancer Research, 72, 6344-6350. https://doi.org/10.1158/0008-5472.CAN-12-1068

[85] Walenta, S., Wetterling, M., Lehrke, M., Schwickert, G., Sundfor, K., Rofstad, E.K. and Mueller-Klieser, W. (2000) High Lactate Levels Predict Likelihood of Metastases, Tumor Recurrence, and Restricted Patient Survival in Human Cervical Cancers. Cancer Research, 60, 916-921.

[86] Newsholme, A.E. and Start, C. (1977) Regulation in Metabolissm. Verlag Chemie, Weinheim, New York, 22.

[87] Kennedy, K.M. and Dewhirst, M.W. (2010) Tumor Metabolism of Lactate: The Influence and Therapeutic Potential for MCT and CD147 Regulation. Future Oncology, 6, 127-148. https://doi.org/10.2217/fon.09.145

[88] Hofmann, E. (1986) Zellbiochemie. In: Hofmann, E., Ed., Dynamische Biochemie Teil IV, Akademie-Verlag, Berlin, 201-206.

[89] Gabbert, H. and Gerharz, C.-D. (1988) Differentiation Induction in Malignant Tumors. Verhandlungen der Deutschen Gesellschaft für Pathologie, 72, 115-127.

[90] Wendel, M., Weiss, M. and Müller, U. (2001) Laktatazidose bei einer Patientin mit hochmalignem Non-Hodgkin-Lymphom. Forum Médical Suisse, No. 50, 1252-1253.

[91] Forsythe, S.M. and Schmidt, G.A. (2000) Sodium Bicarbonate for the Treatment of Lactic Acidosis. Chest, 117, 260-267. https://doi.org/10.1378/chest.117.1.260

[92] Fritsch, P. (2004) Genitale Kontaktinfektionen unter dem Bild der Vulvovaginitis. In: Fritsch, P., Ed., Dermatologie Venerologie, 2nd Edition, Springer-Verlag, Berlin Heidelberg, New York, 956-957.

[93] Taubert, H.-D. and Licht, P. (2005) Geschlechtsspezifische Entwicklung der Frau und ihre Störungen. In: Schmidt-Mathisen, H. and Wallwiener, D., Eds., Gynälologie und Geburtshilfe, 10th Edition, Schattauer Verlag Stuttgart, New York, 81-82.

[94] Wright, V.C. (1969) Vaginal Metastases of Hypernephroma. Case Report and Summary of World Literature. Canadian Medical Association Journal, 100, 816-820.

[95] Moneta, E., Paparella, P.L. and Alcini, E. (1972) Vaginal Metastasis in Hypernephroma: Presentation of a Case Review of the Literature. Annali di Ostetricia, Ginecologia, Medicina Perinatale, 93, 324-338.

[96] Osório, L., Sabell, F., Soares, J., Lima, E. and Marcelo, F. (2008) Vaginal Metastasis from Renal Cell Carcinoma. Actas Urológicas Españolas, 32, 653-655.

[97] Ohgaki, K., Horiuchi, K., Oka, F., Sato, M. and Nishimura, T. (2008) Vaginal Metastasis of Urothelial Carcinoma Found Incidentally during Transurethral Resection 
of a Bladder Tumor. Journal of Nippon Medical School, 75, 312-315. https://doi.org/10.1272/jnms.75.312

[98] McBee, W.C., Brainard, J., Sawady, J. and Rose, P.G. (2007) Yolk Sac Tumor of the Ovary Associated with Endometrioid Carcinoma with Metastasis to the Vagina: A Case Report. Gynecologic Oncology, 105, 244-247. https://doi.org/10.1016/j.ygyno.2006.07.042

[99] Gabril, M.Y. and Yousef, G.M. (2007) Salivary Duct Carcinoma Presenting with Vaginal Metastasis: Case Report. European Journal of Gynaecological Oncology, 28, 415-417.

[100] Marchal, F., Leroux, A., Hoffstetter, S. and Granger, P. (2006) Vaginal Metastasis Revealing Colon Adenocarcinoma. International Journal of Colorectal Disease, 21, 861-862. https://doi.org/10.1007/s00384-004-0734-x

[101] Lialios, G., Plataniotis, G., Kallitsaris, A., Theofanopoulou, M.A., Skoufi, G. and Messinis, I.E. (2005) Vaginal Metastasis from Renal Adenocarcinoma. Gynecologic Oncology, 98, 172-173. https://doi.org/10.1016/j.ygyno.2005.03.024

[102] Jahnke, A., Domke, R., Makovitzky, J., Nizze, H. and Briese, V. (2005) Vaginal Metastasis of Lung Cancer: A Case Report. Anticancer Research, 25, 1645-1648.

[103] Okada, Y., Nishiyama, H., Nakashima, M., Ito, N., Kinoshita, H., Yamamoto, S., Kamoto, T. and Ogawa, O. (2004) A Case of Vaginal Metastasis of Transitional Cell Carcinoma. Hinyokika Kiyo, 50, 283-286.

[104] Allard, J.E., McBroom, J.W., Zahn, C.M., McLeod, D. and Maxwell, G.L. (2004) Vaginal Metastasis and Thrombocytopenia from Renal Cell Carcinoma. Gynecologic Oncology, 92, 970-973. https://doi.org/10.1016/j.ygyno.2003.11.046

[105] Griffin, S.J., Loftus, B., McDermott, T.E. and Grainger, R. (2003) Renal Cell Carcinoma Presenting with Vaginal Metastasis. Irish Medical Journal, 96, 115-116.

[106] Cantisani, V., Mortele, K.J., Kalantari, B.N., Glickman, J.N., Tempany, C. and Silverman, S.G. (2003) Vaginal Metastasis from Uterine Leiomyosarcoma. Magnetic Resonance Imaging Features with Pathological Correlation. Journal of Computer Assisted Tomography, 27, 805-809. https://doi.org/10.1097/00004728-200309000-00020

[107] Katsumoto, Y., Maruyama, K., Furukawa, J., Nagai, K., Maruyama, N., Tanaka, J., Yokouchi, H., Nakaguchi, K. and Sue, F. (2002) A Case of Metastatic Vaginal Tumor of Rectal Cancer. Japanese Journal of Cancer and Chemotherapy, 29, 2406-2409.

[108] Kumar, R., Kumar, S. and Hemal, A.K. (2001) Vaginal and Omental Metastasis from Superficial Bladder Cancer. Urologia Internationalis, 67, 117-118. https://doi.org/10.1159/000050964

[109] Kasai, T., Moriyama, K., Tsuji, M., Uema, K. and Sakurai, N. (2001) A Case of Vaginal Implantation of Transitional Cell Carcinoma of the Bladder. Nihon Hinyokika Gakkai Zasshi, 92, 538-541. https://doi.org/10.5980/jpnjurol1989.92.538

[110] Chagpar, A. and Kanthan, S.C. (2001) Vaginal Metastasis of Colon Cancer. The American Surgeon, 67, 171-172.

[111] Giacalone, P.L., Dumontier, C., Roger, P., Laffargue, F. and Baldet, P. (1998) Vaginal Metastases of Breast Cancer. Journal de Gynécologie Obstétrique et Biologie de la Reproduction, 27, 714-717.

[112] Perrone, A., Gaggioli, A., Di Renzo, D., Arbizzani, V., Emili, E., Lo Gigno, M. and Marcacci, B. (1997) Vaginal Metastasis from Renal Adenocarcinoma. A Clinical Case. Minerva Ginecologica, 49, 405-407. 
[113] Perrotin, F., Bourlier, P. and de Calan, L. (1997) Vaginal Metastasis Disclosing Rectal Adenocarcinoma. Gastroentérologie Clinique et Biologique, 21, 900-901.

[114] Skowronek, J. and Roszak, A. (1997) A Case of Metastatic Malignant Melanoma of the Vagina with a Background of Primary Vaginal Melanoma-Clinical Case. Ginekologia Polska, 68, 390-393.

[115] Martínez Carrancio, L., Monnerat, R., Jesús, C., De la Fuente Buseta, A., Pereiro Alvarez, M. and Zungri Telo, E. (1997) Vaginal Metastasis of Renal Adenocarcinoma: Report of 2 Clinical Cases. Actas Urológicas Españolas, 21, 694-697.

[116] Sánchez López, J.D., Alcalde Escribano, J., Rodríguez Dapena, S., Bayón Lara, A.M., Rodríguez Cuéllar, E., Ibarra Peláez, A., Morales Gutiérrez, C. and Abad Barahona, A. (1997) Vaginal Metastasis of Adenocarcinoma of the Left Colon. Revista Española de Enfermedades Digestivas, 89, 335-336.

[117] Torné, A., Pahisa, J., Castelo-Branco, C., Fábregues, F., Mallofré, C. and Iglesias, X. (1994) Solitary Vaginal Metastasis as a Presenting Form of Unsuspected Renal Adenocarcinoma. Gynecologic Oncology, 52, 260-263.

https://doi.org/10.1006/gyno.1994.1042

[118] Saussine, C., Delepaul, B. and Jacqmin, D. (1994) Vaginal Metastasis from Cancer of the Kidney. Progrès en Urologie, 4, 95-97.

[119] Rosenfeld, P.A. and Lowe, B.A. (1990) Solitary Metastasis of Renal Adenocarcinoma to the Vagina. A Case Report. The Journal of Reproductive Medicine, 35, 295-296.

[120] Ovesen, H. and Gerstenberg, T. (1990) Vaginal Metastasis as the First Sign of Renal Cell Carcinoma. A Case Report and Review of the Literature. Scandinavian Journal of Urology and Nephrology, 24, 237-238. https://doi.org/10.3109/00365599009180868

[121] Serretta, V., Pavone, C., Messina, G., Caramia, G. and Pavone-Macaluso, M. (1989) Vaginal Metastasis from Renal Cell Carcinoma: The Role of Electron Microscopy. European Urology, 16, 78-79. https://doi.org/10.1159/000471537

[122] Murai, M., Nakamura, H., Shinoda, M., Ohashi, M. and Tazaki, H. (1989) Vaginal Metastasis from Transitional Cell Carcinoma of Renal Pelvis in Horseshoe Kidney. Urology, 33, 477-480. https://doi.org/10.1016/0090-4295(89)90136-2

[123] O’Reilly, A.P., McLeod, F. and Craft, I. (1984) Hypernephroma Presenting as a Vaginal Metastasis. Case Report. British Journal of Obstetrics and Gynaecology, 91, 812-815. https://doi.org/10.1111/j.1471-0528.1984.tb04856.x

[124] Porena, M., Virgili, G., Lombi, R., Micheli, C. and Mearini, E. (1983) Vaginal Metastasis from Unsuspected Renal Cell Carcinoma. Clinical and Experimental $\mathrm{Ob}$ stetrics and Gynecology, 10, 135-139.

[125] Itskovitz, J., Kerner, H. and Brandes, J.M. (1981) Solitary Vaginal Metastasis from Renal Carcinoma (Concurrent with Endometrial Carcinoma). British Journal of Urology, 53, 388. https://doi.org/10.1111/j.1464-410X.1981.tb03206.x

[126] Nocks, B.N. and Sacknoff, E.J. (1980) Vaginal Metastasis of Renal Carcinoma without Renal Vein Involvement. British Journal of Urology, 52, 327.

https://doi.org/10.1111/j.1464-410X.1980.tb08931.x

[127] Höffken, H. and Rummel, H.H. (1979) Vaginal Metastases as the ist Signs of Primary Occult Hypernephroid Kidney Neoplasms. Fortschritte der Medizin, 97, 1854-1857.

[128] Sogani, P.C. and Whitmore, W.F. (1979) Solitary Vaginal Metastasis from Unsuspected Renal Cell Carcinoma. Journal of Urology, 121, 95-97.

https://doi.org/10.1016/S0022-5347(17)56678-1 
[129] Pineda, A. and Sall, S. (1978) Metastasis to the Vagina from Carcinoma of the Breast. The Journal of Reproductive Medicine, 20, 243-245.

[130] Redman, J.F. and Roman-Lopez, J.J. (1977) Renal Cell Carcinoma and Vaginal Metastasis. Urology, 10, 148-149. https://doi.org/10.1016/0090-4295(77)90015-2

[131] Carl, P. and Marx, F.J. (1977) Vaginal Metastasis of Renal Carcinoma. Geburtshilfe und Frauenheilkunde, 37, 939-941.

[132] Ponthieu, A., Guidicelli, C. and Hermanowicz, M. (1977) Vaginal Metastasis of Cancer of the Left Kidney with Retro-Aortic Venous Drainage. Journal of Urology and Nephrology (Paris), 83, 880-883.

[133] Yamasaki, M., Ueda, G., Sato, Y., Kurachi, K. and Inoue, M. (1975) A Case of Hypernephroma Metastasis to the Vagina. Acta Obstetrica et Gynaecologica Japonica, 22, 67-71.

[134] Weitzner, S. and Dressner, S.A. (1974) Vaginal Metastasis from Adenocarcinoma of Pancreas. The American Surgeon, 40, 256-258.

[135] Kawabe, K. and Kawamura, T. (1973) Vaginal Metastasis from Transitional Cell Carcinoma of the Left Renal Pelvis. Annales Chirurgiae et Gynaecologiae Fenniae, 62, 169-171.

[136] Suhler, A. and Garbay, B. (1972) Vaginal Metastasis from a Pyelic Epithelioma. Journal of Urology and Nephrology (Paris), 78, 290-292.

[137] Mulcahy, J.J. and Furlow, W.L. (1970) Vaginal Metastasis from Renal Cell Carcinoma: Radiographic Evidence of Possible Route of Spread. Journal of Urology, 104, 50-52. https://doi.org/10.1016/S0022-5347(17)61669-0

[138] Boutellier, Urs. and Ulmer, H.-V. (2007) Sport-und Arbeitsphysiologie. In: Schmid, R.F. and Lang, F., Eds., Physiologie des Menschen, 29th Edition, Springer Medizin-Verlag, Heidelberg, 928-952. https://doi.org/10.1007/978-3-540-32910-7_40

[139] Stutte, H.J. (1999) Milz. In: Remmele, W., Ed., Pathologie Bd. 1,2. Aufl. Springer-Verlag, Berlin, Heidelberg, New York, 551-652.

https://doi.org/10.1007/978-3-642-58620-0_12

[140] Rogozina, O.P., Nkhata, K.J., Nagle, E.J., Grande, J.P. and Cleary, M.P. (2013) The Protective Effect of Intermittent Calorie Restriction on Mammary Tumorigenesis Is Not Compromised by Consumption of a High Fat Diet during Refeeding. Breast Cancer Research and Treatment, 138, 395-405. https://doi.org/10.1007/s10549-013-2464-7

[141] Seyffert, W. (2003) Lehrbuch der Genetik. 2nd Edition, Spektrum Akademischer Verlag GmbH, Heidelberg Berlin, 692-694.

[142] Blomqvist, G., Skolnik, G., Braide, M., Bjursten, L.M., Blixt, A. and Bagge, U. (1988) Differences in Lodgement of Tumor Cells in Muscle and Liver. Clinical \& Experimental Metastasis, 6, 285-289. https://doi.org/10.1007/BF01753575

[143] Baumgartner-Parzer, S.M. (1996) Apoptosis-Programmed Cell Death. Wiener klinische Wochenschrift, 108, 311-320.

[144] Helbing, C.C., Wellington, C.L., Gogela-Spehar, M., Cheng, T., Pinchbeck, G.G. and Johnston, R.N. (1998) Quiescence versus Apoptosis: Myc Abundance Determines Pathway of Exit from the Cell Cycle. Oncogene, 17, 1491-1501. https://doi.org/10.1038/sj.onc.1202241

[145] Elias, S.G., Peeters, P.H., Grobbee, D.E. and van Noord, P.A. (2007) Transient Caloric Restriction and Cancer Risk (The Netherlands). Cancer Causes Control, 1, 1-5. https://doi.org/10.1007/s10552-006-0080-0 
[146] Nörrelund, H., Riis, A.L. and Möller, N. (2002) Effects of GH on Protein Metabolism during Dietary Restriction in Man. Growth Hormone \& IGF Research, 12, 198-207. https://doi.org/10.1016/S1096-6374(02)00043-6

[147] Sylvester, P.W., Aylsworth, C.F. and Meites, J. (1981) Relationship of Hormones to Inhibition of Mammary Tumor Development by Underfeeding during the "Critical Period" after Carcinogen Administration. Cancer Research, 4, 1384-1388.

[148] Lehninger, A.L. (1987) Biochemistry. 2th Edition, VCH, Weinheim, 300-303.

[149] Liu, B. and Qian, S.B. (2011) Translational Regulation in Nutrigenomicx. Advances in Nutrition, 2, 511-519. https://doi.org/10.3945/an.111.001057

[150] Buddecke, E. and Fischer, M. (1992) Pathophysiologie, Pathobiochemie, klinische Chemie. Walter de Gruyter, Berlin, New York, 155-206. https://doi.org/10.1515/9783110888089

[151] Jansen, O.E. (2004) Schilddrüsenhormonwirkung. In: Gärtner, R., Ed., Schilddrüsenerkrankungen, Wissenschaftliche Verlagsgesellschaft $\mathrm{mbH}$ Stuttgart, 52-67.

[152] Ultmann, J.E., Hyman, G.A. and Calder, B. (1963) The Occurrence of Lymphoma in Patients with Long-Standing Hyperthyroidism. Blood, 21, 282-297.

[153] Baris, D., Gridley, G., Ron, E., Weiderpass, E., Mellemkjaer, L., Ekbom, A., Olsen, J.H., Baron, J.A. and Fraumeni, J.F. (2002) Acromegaly and Cancer Risk: A Cohort Study in Sweden and Denmark. Cancer Causes Control, 13, 395-400. https://doi.org/10.1023/A:1015713732717

[154] Higuchi, Y., Saeki, N., Iuchi, T., Uchino, Y., Tatsuno, I., Uchida, D., Tanaka, T., Noguchi, Y., Nakamura, S., Yasuda, T., Yamaura, A., Sunami, K., Oka, Y. and Uozumi, A. (2000) Incidence of Malignant Tumors in Patients with Acromegaly. Endocrine Journal, 47, S57-S60. https://doi.org/10.1507/endocrj.47.SupplMarch_S57

[155] Orme, S.M., McNally, R.J., Cartwright, R.A. and Belchetz, P.E. (1998) Mortality and Cancer Incidence in Acromegaly: A Retrospective Cohort Study. United Kingdom Acromegaly Study Group. The Journal of Clinical Endocrinology \& Metabolism, 83, 2730-2734.

[156] Popovic, V., Damjanovic, S., Micic, D., Nesovic, M., Djurovic, M., Petakov, M., Obradovic, S., Zoric, S., Simic, M., Penezic, Z. and Marinkovic, J. (1998) Increased Incidence of Neoplasia in Patients with Pituitary Adenomas. The Pituitary Study Group. Clinical Endocrinology, 49, 441-445. https://doi.org/10.1046/j.1365-2265.1998.00536.x

[157] Cheung, N.W. and Boyages, S.C. (1997) Increased Incidence of Neoplasia in Females with Acromegaly. Clinical Endocrinology, 47, 323-327. https://doi.org/10.1046/j.1365-2265.1997.2561053.x

[158] Barzilay, J., Heatley, G.J. and Cushing, G.W. (1991) Benign and Malignant Tumors in Patients with Acromegaly. Archives of Internal Medicine, 151, 1629-1632. https://doi.org/10.1001/archinte.1991.00400080113022

[159] Ron, E., Gridley, G., Hrubec, Z., Page, W., Arora, S. and Fraumeni, J.F. (1992) Acromegaly and Gastrointestinal Cancer. Cancer, 68, 1673-1677.

https://doi.org/10.1002/1097-0142(19911015)68:8<1673::AID-CNCR2820680802>3. 0.CO;2-0

[160] Ritchie, C.M., Atkinson, A.B., Kennedy, A.L., Lyons, A.R., Gordon, D.S., Fannin, T. and Hadden, D.R. (1990) Ascertainment and Natural History of Treated Acromegaly in Northern Ireland. Ulster Medical Journal, 59, 55-62. 
[161] Nabarro, J.D. (1987) Acromegaly. Clinical Endocrinology, 26, 481-512. https://doi.org/10.1111/j.1365-2265.1987.tb00805.x

[162] Munoz, J.M., Gorman, C.A., Elveback, L.R. and Wentz, J.R. (1978) Incidence of Malignant Neoplasms of All Types of Patients with Graves' Disease. Archives of Internal Medicine, 138, 944-947. https://doi.org/10.1001/archinte.1978.03630310034015

[163] Wanebo, H.J., Benua, R.S. and Rawson, R.W. (1966) Neoplastic Disease and Thyrotoxicosis. Cancer, 19, 1523-1526. https://doi.org/10.1002/1097-0142(196611)19:11<1523::AID-CNCR2820191110>3.0 .CO;2-D

[164] Liechty, R.D., Hodges, R.D. and Burket, J. (1963) Cancer and Thyroid Function. $J A M A, 183,30-32$. https://doi.org/10.1001/jama.1963.63700010003014a

[165] Unnikrishnan, A.G., Agrawal, N.K., Kumar, B., Thazhath, S.S., Reddy, D.V. and Singh, S.K. (2003) Toxic Thyroid Adenoma and Acromegaly: An Unusual Association. Journal of the Association of Physicians of India, 51, 412-413.

[166] Murphy, P.T., Ahmed, N. and Hassan, H.T. (2002) Chronic Myeloid Leukemia and Acromegaly in POEMS Syndrome. Leukemia Research, 26, 1135-1137. https://doi.org/10.1016/S0145-2126(02)00076-0

[167] Marzullo, P., Cuocolo, A., Ferone, D., Pivonello, R., Salvatore, M., Lombardi, G. and Colao, A. (2000) Cardiac Effect of Thyrotoxicosis in Acromegaly. The Journal of Clinical Endocrinology \& Metabolism, 85, 1426-1432. https://doi.org/10.1210/jc.85.4.1426

[168] Holt, R.I., Powrie, J.K. and Sönksen, P.H. (2000) Acromegaly, Primary Thyrotoxicosis, a Dense Left Hemipareses and a Right Internal Carotid Aneurysm. Journal of the Royal Society of Medicine, 93, 636-638. https://doi.org/10.1177/014107680009301208

[169] Shimatsu, A., Murabe, H., Nakamura, Y., Misuta, H., Ihara, C. and Nakao, K. (1999) Long-Term Treatment with Bromocriptine of a Plurihormonal Pituitary Adenoma Secreting Thyrotropin, Growth Hormone and Prolactin. Endocrine Journal, 46, 159-165. https://doi.org/10.1507/endocrj.46.159

[170] Ozawa, Y., Kameya, T., Kasuga, A., Naritaka, H., Kanda, N., Maruyama, H. and Saruta, T. (1998) A Functional Thyrotropin- and Growth Hormone-Secreting Pituitary Adenoma with a Ultrastructurally Monomorphic Feature: A Case Study. Endocrine Journal, 45, 211-219. https://doi.org/10.1507/endocrj.45.211

[171] Burgos Peláez, R., Simó Canonge, R., Hernández-Pascual, C. and Mesa Manteca, J. (1994) Acromegaly and Graves-Basedow Disease. Report of 3 Cases. Medicina clínica, 103, 179-180.

[172] Links, T.P., Monkelbaan, J.F., Dullaart, R.P. and van Haeften, T.W. (1993) Growth Hormone-, Alpha-Subunit and Thyrotrophin-Cosecreting Pituitary Adenoma in Familial Setting of Pituitary Tumour. Acta Endocrinologica (Copenhagen), 129, 516-518. https://doi.org/10.1530/acta.0.1290516

[173] Wüster, C., Steger, G., Schmelzle, A., Gottswinter, J., Minne, H.W. and Ziegler, R. (1991) Increased Incidence of Euthyroid and Hyperthyroid Goiters Independently of Thyrotropin in Patients with Acromegaly. Hormone and Metabolic Research, 23, 131-134. https://doi.org/10.1055/s-2007-1003632

[174] Hirasawa, R., Hashimoto, K., Makino, S., Suemaru, S., Takao, T., Ota, Z., Hoshida, Y., Yoshino, T. and Akagi, T. (1991) Effect of a Long-Acting Somatostatin Analogue (SMS 201-995) on a Growth Hormone and Thyroid Stimulating Hormone-Producing 
Pituitary Tumor. Acta Medica Okayama, 45, 107-115.

[175] Shimatsu, A., Murabe, H., Sasaki, S., Hattori, N., Tanoh, T. and Imura, H. (1990) Secretory Dynamics of Growth Hormone in an Acromegalic Patient Associated with Graves' Disease. The Journal of Clinical Endocrinology \& Metabolism, 71, 1059-1063. https://doi.org/10.1210/jcem-71-4-1059

[176] Malarkey, W.B., Kovacs, K. and O’Dorisio, T.M. (1989) Response of a GH- and TSH-Secreting Pituitary Andenoma to a Somatostatin Analogue (SMS 201-995): Evidence That GH and TSH Coexist in the Same Cell and Secretory Granules. Neuroendocrinology, 49, 267-274. https://doi.org/10.1159/000125127

[177] Tindall, H. and Wales, J.K. (1989) Primary Hyperthyroidism Occurring in Association with Acromegaly. British Journal of Clinical Practice, 43, 177-179.

[178] Misaki, M., Shima, T., Ikoma, J., Morioka, K. and Suzuki, S. (1988) Acromegaly and Hyperthyroidism Associated with McCune-Albright Syndrome. Hormone Research, 30, 26-27. https://doi.org/10.1159/000181021

[179] Yoshinari, M., Tokuyama, T., Okamura, K., Sato, K., Kusuda, K. and Fujishima, M. (1988) Iodide-Induced Thyrotoxicosis in a Thyroidectomized Patient with Metastatic Thyroid Carcinoma. Cancer, 61, 1674-1678.

https://doi.org/10.1002/1097-0142(19880415)61:8<1674::AID-CNCR2820610827>3. $\underline{0 . \mathrm{CO} ; 2-\mathrm{E}}$

[180] Kumawat, D.C., Bomb, B.S., Agarwal, H.K. and Bhatnagar, H.N. (1987) The Albright Syndrome Associated with Acromegaly and Hyperthyroidism (a Case Report). Journal of Postgraduate Medicine, 33, 155-157.

[181] Beck-Peccoz, P., Piscitelli, G., Amr, S., Ballabio, M., Bassetti, M., Giannattasio, G., Spada, A., Nissim, M., Weitraub, B.D. and Faglia, G. (1986) Endocrine, Biochemical, and Morphological Studies of a Pituitary Adenoma Secreting Growth Hormone, Thyrotropin (TSH), and Alpha-Subunit: Evidence for Secretion of TSH with Increased Bioactivity. The Journal of Clinical Endocrinology \& Metabolism, 62, 704-711. https://doi.org/10.1210/jcem-62-4-704

[182] Seif, F.J., Scherbaum, W.A., Knisel, W., Feine, U. and Meinke, J. (1985) Goiter, Thyroid Autonomy and Hyperthyroidism in Acromegaly. 6. Konferenz über die menschliche Schilddrüse Homburg/Saar, 340-344.

[183] Eitel, B. (1985) Coincidence of Hypophyseal Adenoma and Thyrogenic Hyperthyroidism. Zeitschrift fur die Gesamte Innere Medizin und Ihre Grenzgebiete, 40, 606-608.

[184] Demura, R., Demura, H., Odagiri, E. and Shizume, K. (1984) A Case of Acromegaly Associated with Graves' Disease. A Possible Role of Endogenous TRH and an Effect of Bromocriptine on GH and TSH Secretion. Endocrinologia Japonica, 31, 801-807. https://doi.org/10.1507/endocrj1954.31.801

[185] Present, D., Bertoni, F. and Enneking, W.F. (1986) Osteosarcoma of the Mandible Arising in Fibrous Dysplasia. A Case Report. Clinical Orthopaedics and Related Research, 204, 238-244.

[186] Carlson, H.E., Linfoot, J.A., Braunstein, G.D., Kovacs, K. and Young, R.T. (1983) Hyperthyroidism and Acromegaly Due to a Thyrotropin- and Growth Hormone-Secreting Pituitary Tumor. Lack of Hormonal Response to Bromocriptine. American Journal of Medicine, 74, 915-923. https://doi.org/10.1016/0002-9343(83)91086-0

[187] Lamberg, B.A., Pelkonen, R., Gordin, A., Haltia, M., Wahlström, T., Paetau, A. and Leppäluoto, J. (1983) Hyperthyroidism and Acromegaly Caused by a Pituitary TSHand GH-Secreting Tumour. Acta Endocrinologica (Copenhagen), 103, 7-14. 
https://doi.org/10.1530/acta.0.1030007

[188] Meinders, A.E., Willekens, F.L., Barends, C.A., Seevinck, J. and Nieuwenhuijzen Kruseman, A.C. (1981) Acromegaly and Thyrotoxicosis Induced by a GH- and TSH-Producing Pituitary Tumour Which Also Contained Prolactin. The Netherlands Journal of Medicine, 24, 136-144.

[189] Duron, F., Trinchet, J.C., Roudiert, M., Thomas, M. and Aubert, P. (1978) Hyperthyroidie et acromégalie. Tumeur Hypophysaire. Annales de Medecine Interne (Paris), 129, 533-537.

[190] Thomas, M., Scheinmann, N., Klotz, B. and Perrault, M. (1977) Acromégalie, hyperthyréose et hypercalcémie. Annales de Medecine Interne (Paris), 128, 979-982.

[191] Lamberg, B.A., Pelkonen, R., Aro, A. and Grahne, B. (1976) Thyroid Function in Acromegaly before and after Transsphenoidal Hypophysectomy Followed by Cryoapplication. Acta Endocrinologica (Copenhagen), 82, 254-266. https://doi.org/10.1530/acta.0.0820254

[192] Sandler, R. (1976) Recurrent Hyperthyroidism in an Acromegalic Patient Previously Treated with Broton Beam Irradiation: Craves' Disease as Probable Etiology Based on Follow-Up Observations. The Journal of Clinical Endocrinology \& Metabolism, 42, 163-168. https://doi.org/10.1210/jcem-42-1-163

[193] Hamilton, C.R. and Maloof, F. (1972) Acromegaly and Toxic Goiter. Cure of the Hyperthyroidism and Acromegaly by Proton-Beam Partial Hypophysectomy. The Journal of Clinical Endocrinology \& Metabolism, 35, 659-664. https://doi.org/10.1210/jcem-35-5-659

[194] Pickard, C.R. and Scriba, P.C. (1970) Growth of the Thyroid Gland and Thyroid Hyperfunction in Anterior Pituitary Insufficiencyl. Deutsche Medizinische Wochenschrift, 95, 2166-2169.

[195] Lamberg, B.A., Ripatti, J., Gordin, A., Juustila, H., Sivula, A. and af Björkesten, G. (1969) Chromophobe Pituitary Adenoma with Acromegaly and TSH-Induced Hyperthyroidism Associated with Parathyroid Adenoma. Acromegaly and Parathyroid Adenoma. Acta Endocrinologica (Copenhagen), 60, 157-172.

[196] Heaney, J.P., James, C.L., Spurr, C.L. and Bakey, M.E. (1955) Case of Acromegaly Associated with Thyrotoxicosis: Review of Literature. The Archives of Surgery, 71, 279-287. https://doi.org/10.1001/archsurg.1955.01270140127024

[197] Junet, R. (1955) A Rare Form of Hyperthyreosis: Hyperostosis of the Cranial Vault in Hyperthyroid Acromegaly (Troll-Junet's Syndrome). Helvetica Medica Acta, 22, 167-183.

[198] Bothe, F.A. (1944) Hypertension in a Case of Hyperthyroidism Associated with Acromegaly. Surgical Clinics of North America, 24, 1365-1369.

[199] Davis, A.C. (1941) The Thyroid Gland in 166 Cases of Acromegaly. The Journal of Clinical Endocrinology \& Metabolism, 1, 445. https://doi.org/10.1210/jcem-1-5-445

[200] Pollack, A. (2005) To Fight Cancer, a Vast U.S. Genome Project ist Proposed. International Herald Tribune on March 28th 2005.

[201] Stebbins, G.L. (1977) Explosive Artenbildung (transl.). In: Ledyard Stebbins, G., Ed., Processes of Organic Evolution, 3rd Edition, Prentice-Hall Inc., Englewood Cliffs, 139.

[202] Lodish, H., Berk, A., Kaiser, C.A., Krieger, M., Bretscher, A., Ploegh, H., Amon, A. and Scott, M. (2013) Molecular Cell Biology. 7th Edition, W.H. Freeman and Company, New York, 1119-1120.

[203] Alberts, B., Johnson, A., Lewis, J., Raff, M., Roberts, K. and Walter, P. (2004) Mo- 
lecular Biology of the Cell. 4th Edition, Wiley-VCH Verlag Gmbh \& Co KgaA, Weinheim, 1533-1592.

[204] Bannasch, P. (1991) Neoplasmen. In: Hierholzer, K. and Schmidt, R.F., Eds., Pathophysiologie des Menschan, VCH Verlagsgesellschaft mbH, D-69451 Weinheim (FRG), 4.1-4.42.

[205] Karp, C.G. (2005) Cell and Molecular Biology. 4th Edition, Wiley, New York, 829-868.

[206] Berkow, R. (1992) The Merck Manual of Diagnosis and Therapy. 16th Edition, Merck Publishing Group, Rahway.

[207] Schmidt, C.G. (1961) On the Relation between DPN (Diphosphopyridine Nucleotide) Concentration and Inhibition of Glycolysis in Tumor Cells by Carcinophilin. Zeitschrift fur Krebsforschung, 64, 156-168. https://doi.org/10.1007/BF00525082

[208] Dillon, P.F. and Root-Bernstein, R.S. (1997) Molecular Complementarity II: Energetic and Vectorial Basis of Biological Homeostasis and Its Implications for Death. Journal of Theoretical Biology, 188, 481-493. https://doi.org/10.1006/jtbi.1997.0477

[209] Herrmann, R. (1989) Metastasenchirurgie aus der Sicht des internistischen Onkologen. In: Rothmund, M., Ed., Metastasenchirurgie, Thieme, Stuttgart, New York, 209-215.

[210] Luo, Y., Yoneda, J., Ohmori, H., Sadaki, T., Shimbo, K., Eto, S., Kato, Y., Miyano, H., Kobayashi, T., Sasahira, T., Chihara, Y. and Kuniyasu, H. (2014) Cancer Usurps Skeletal Muscle as an Energy Repository. Cancer Research, 74, 330-340. https://doi.org/10.1158/0008-5472.CAN-13-1052

[211] Rett, K., Wicklmayr, M., Baldermann, H., Schwiegelshohn, B., Dietze, G. and Mehnert, H. (1988) Inhibition of Muscle Amino Acid Release by Infusion of a Triglyceride Emulsion. Infusionstherapie, 15, 78-82.

[212] Luo, W., Schork, N.J., Marschke, K.B., Ng, S.C., Hermann, T.W., Zhang, J., Sanders, J.M., Tooker, P., Malo, N., Zapala, M.A., Dziewanowska, Z.E., Negro-Vilar, A. and Meglasson, M.D. (2011) Identification of Polymorphisms Associated with Hypertriglyceridemia and Prolonged Survival Induced by Bexarotene in Treating Non-Small Cell Lung Cancer. Anticancer Research, 31, 2303-2311.

[213] Dragnev, K.H., Ma, T., Cyrus, J., Galimberti, F., Memoli, V. and Busch, A.M., Tsongalis, G.J., Seltzer, M., Johnstone, D., Erkmen, C.P., Nugent, W., Rigas, J.R., Liu, X., Freemantle, S.J., Kurie, J.M., Waxman, S. and Dmitrovsky, E. (2011) Bexarotene plus Erlotinib Suppress Lung Carcinogenesis Independent of KRAS Mutations in Two Clinical Trials and Transgenic Models. Cancer Prevention Research, 4, 818-828. https://doi.org/10.1158/1940-6207.CAPR-10-0376

[214] Malik, S.M., Collins, B., Pishvaian, M., Ramzi, P., Marshall, J. and Hwang, J. (2011) A Phase I Trial of Bexarotene in Combination with Docetaxel in Patients with Advanced Solid Tumors. Clinical Lung Cancer, 12, 231-236. https://doi.org/10.1016/j.cllc.2011.03.024

[215] Poff, A.M., Ari, C., Arnold, P., Seyfried, T.N. and D’Agostino, D.P. (2014) Detone Supplementation Decreases Tumor Cell Viability and Prolongs Survival of Mice with Metastatic Cancer. International Journal of Cancer, 135, 1711-1720. https://doi.org/10.1002/ijc.28809

[216] Söling, H.-D. (1991) Stoffwechselkrankheiten. In: Hierholzer, K. and Schmidt, R.F., Eds., Pathophysiologie des Menschen, VCH Verlagsgesellschaft mbH, D-69451, Weinheim (FRG), 18.1-18.49.

[217] Newton, R.U. and Galvao, D.A. (2008) Exercise in Prevention and Management of 
Cancer. Current Treatment Options in Oncology, 9, 135-146. https://doi.org/10.1007/s11864-008-0065-1

[218] Austin, L., Bower, J.J., Bennett, T.M., Lynch, G.S., Kapsa, R., White, J.D., Barnard, W., Gregorevic, P. and Byrne, E. (2000) Leukemia Inhibitory Factor Ameliorates Muscle Fiber Degeneration in the Mdx Mouse. Muscle \& Nerve, 23, 1700-1705. https://doi.org/10.1002/1097-4598(200011)23:11<1700::AID-MUS5>3.0.CO;2-W

[219] Broholm, C., Mortensen, O.H., Nielsen, S., Akerstrom, T., Zankari, A., Dahl, B. and Pedersen, B.K. (2008) Exercise Induces Expression of Leukaemia Inhibitory Factor in Human Skeletal Muscle. The Journal of Physiology, 586, 2195-2201. https://doi.org/10.1113/jphysiol.2007.149781

[220] Steinke, J. and Beyer, J. (1977) Spontanhypoglykämien. In: Schwiegk, H., Ed., Handbuch der Inneren Medizin VII Band, Stoffwechselkrankheiten, 5th Edition, Teil 2B Springer-Verlag, Berlin Heidelberg, New York, 709. https://doi.org/10.1007/978-3-642-66379-6_14

[221] Heymsfield, S.B. and McManus, C.M. (1985) Tissue Components of Weight Loss in Cancer Patients. A New Method of Study and Preliminary Observations. Cancer, 55, 238-249.

https://doi.org/10.1002/1097-0142(19850101)55:1+<238::AID-CNCR2820551306>3. $\underline{0 . \mathrm{CO} ; 2-\mathrm{S}}$

[222] Yanez, A.J., Nualart, F., Droppelmann, C., Bertinat, R., Brito, M., Concha, I.I. and Slebe, J.C. (2003) Broad Expression of Fructose-1,6-Bisphosphatase and Phosphoenolpyruvate Carboxykinase Provide Evidence for Gluconeogenesis in Human Tissues Other than Liver and Kidney. Journal of Cellular Physiology, 197, 189-197. https://doi.org/10.1002/jcp.10337

[223] Petrides, P.E. (1997) Muskelgewebe. In: Löffler, G. and Petrides, P.E., Eds., Biochemie und Pathobiochemie, 5th Edition, Springer-Verlag, Berlin, 949-971. https://doi.org/10.1007/978-3-662-06062-9_32

[224] Shukla, S.K., Gebregiworgis, T., Purohit, V., Chaika, N.V., Gunda, V., Radhakrishnan, P., et al. (2014) Metabolic Reprogramming Induced by Ketone Bodies Diminishes Pancreatic Cancer Cachexia. Cancer \& Metabolism, 2, 18. https://doi.org/10.1186/2049-3002-2-18

[225] Zhu, Z., Haegele, A.D. and Thompson, H.J. (1997) Effect of Caloric Restriction on Pre-Malignant and Malignant Stages of Mammary Carcinogenesis. Carcinogenesis, 18, 1007-1012. https://doi.org/10.1093/carcin/18.5.1007

[226] Ollenschläger, G. (2004) Ernährung und Krebs. In: Hiddemann, W., Huber, H. and Bartram, C.R., Eds., Die Onkologie, Springer-Verlag, Berlin Heidelberg, 310-323. https://doi.org/10.1007/978-3-662-06670-6_12

[227] Keller, U. (1991) Physische und biochemische Charakteristika der Tumorkachexie. In: Schauder, P., Ed., Ernährung und Tumorerkrankungen, Karger, Basel, 213-222. https://doi.org/10.1159/000420261

[228] Lee, D.E., Brown, J.L., Rosa-Caldwell, M.E., Blackwell, T.A., Perry, R.A., Brown, L.A., Khatri, B., Seo, D., Bottje, W.G., Washington, T.A., Wiggs, M.P., Kong, B.W. and Greene, N.P. (2017) Cancer Cachexia-Induced Muscle Atrophy: Evidence for Alterations in microRNAs important for Muscle Size. Physiological Genomics, 49, 253-260. https://doi.org/10.1152/physiolgenomics.00006.2017

[229] Sontag, E.M., Vonk, W.I. and Frydman, J. (2014) Sorting out the Trash: The Spatial Nature of Eukaryotic Protein Quality Control. Current Opinion in Cell Biology, 26, 139-146. https://doi.org/10.1016/j.ceb.2013.12.006

[230] Rapoport, S.M. (1965) Medizinische Biochemie 3. Auflage. V.E.B-Verlag Volk und 
Gesundheit, Berlin, 775.

[231] Hossfeld, D.K. (1997) Krebs ist unbesiegbar. Spiegel, 39, 210-216.

[232] Monod, J. (1971) Le hasard et la nécessité. Ed. du Seuil, Paris 1970 (Transl.), R. Piper \& Co., Verlag, München, 149.

[233] Bonnet, S., Archer, S.L., Allalunis-Turner, J., Haromy, A., Beaulieu, C., Thompson, R., Lee, C.T., Lopaschuk, G.D., Puttagunta, L., Bonnet, S., Harry, G., Hashimoto, K., Porter, C.J., Andrade, M.A., Thebaud, B. and Michelakis, E.D. (2007) A Mitochondria- $\mathrm{K}^{+}$Channel Axis Is Suppressed in Cancer and Its Normalization Promotes Apoptosis and Inhibits Cancer Growth. Cancer Cell, 11, 37-51. https://doi.org/10.1016/j.ccr.2006.10.020

[234] Becker, N. (2006) Epidemiologie von Tumoren. In: Schmoll, H.-J., Höffken, K. and Possinger, K., Eds., Kompendium Internistische Onkologie, 4th Edition, Springer Medizin Verlag, Heidelberg, 187-240. https://doi.org/10.1007/3-540-31303-6_12

[235] Bailar, J.C. and Gornik, H.L. (1997) Cancer Undefeated. The New England Journal of Medicine, 336, 1569-1574. https://doi.org/10.1056/NEJM199705293362206 